\title{
ZIRCON AGES, Sr-Nd-Hf ISOTOPIC COMPOSITIONS, AND \\ GEOCHEMISTRY OF GRANITOIDS ASSOCIATED WITH THE NORTHERN OPHIOLITE MÉLANGE OF GENTRAL CUBA: TECTONIC IMPLICATION FOR LATE CRETACEOUS MAGMATISM IN THE NORTHWESTERN CARIBBEAN
}

\author{
YAMIRKA ROJAS-AGRAMONTE* ${ }^{\dagger}$, ALFRED KRÖNER*, \\ ANTONIO GARCÍA-CASCO**, TONY KEMP***, ERNST HEGNER ${ }^{\S}$, \\ MIREYA PÉREZ ${ }^{\$ \S}$, MATTHIAS BARTH*, DUNYI LIU ${ }^{\$ \$ \$}$, \\ and ALAIN FONSECA-MONTERO ${ }^{\S}$
}

\begin{abstract}
The geology of Cuba is representative of the orogenic belt fringing the northwesternmost margin of the Caribbean plate. It is characterized by a tectonic collage made up of a continental margin, volcanic arc, and ophiolitic and subduction complexes formed as a result of collision between the leading edge of the Caribbean plate and the Caribeana terrane in the latest Cretaceous to early Tertiary and by oblique convergence with the continental margin of the North American plate during Tertiary times.
\end{abstract}

The northern ophiolite belt of central Cuba consists of a mélange containing blocks of eclogite, garnet-amphibolite, amphibolite, blueschist, greenschist, quartzite, metapelite, antigoritite and various types of intrusive rocks that occur as blocks or intrusive gabbro and diabase of the ophiolitic sequence. We present the first combined SHRIMP zircon U-Pb ages, $\mathrm{Sr}-\mathrm{Nd}$-Hf isotopic compositions as well as major and trace element data for nine arc-related granitoid rocks from the northern ophiolite mélange of central Cuba. A trondhjemite from the Cerro el Chivo area south of Santa Clara, provided a concordant zircon age of $\sim 86 \mathrm{Ma}$, whereas a granite and a tonalite from the Las Bocas body, north of Placetas, yielded ages of $\sim 75 \mathrm{Ma}$. Two peraluminous trondhjemitic samples taken from the Tres Guanos area $S$ of Perea yielded zircon crystallization ages of $\sim 72$ and $\sim 74 \mathrm{Ma}$, rare Cambrian $(\sim 536 \mathrm{Ma})$ and Permian $(\sim 268$ Ma) inherited zircons were found in these samples. Hf isotope ratios were measured in five of the dated zircon grains from the Tres Guanos samples. The three youngest zircons, with ages of $\sim 72$ and $\sim 74 \mathrm{Ma}$, show derivation from a depleted source region, as can be expected for arc granitoids, as well as the oldest xenocryst $(\sim 536 \mathrm{Ma})$ which is less depleted but still from a juvenile Pan-African source. A Permian xenocryst $(\sim 268 \mathrm{Ma})$ has a negative $\varepsilon_{\mathrm{Hf}(T)}$ value $(-2.35)$, implying that the zircon is derived from a continental source. The initial $\mathrm{Nd}$ isotopic composition $\varepsilon_{\mathrm{Nd}(\mathrm{t})}$ of four of the dated granitoids is almost identical at 7.3 to 7.7 and implies a depleted source, whereas one of the Tres Guanos trondhjemite samples containing an inherited Cambrian zircon has a lower $\varepsilon_{\mathrm{Nd}(\mathrm{t})}$ of 4.9 , possibly reflecting input from an older crustal component. The initial $\mathrm{Sr}$ isotopic compositions of all five analyzed samples vary between 0.7031 and

* Institut für Geowissenschaften, Universität Mainz, Becherwig 21, 55099 Mainz, Germany, and SHRIMP Center, Institute of Geology, Chinese Academy of Geological Sciences, 26 Baiwanzhuang Road, Beijing, 100037, China; kroener@mail.uni-mainz.de; barthm@uni-mainz.de

** Departamento de Mineralogía y Petrología, Instituto Andaluz de Ciencias de la Tierra, Fuentenueva s/n, Universidad de Granada-CSIC, 18002-Granada, Spain; agcasco@ugr.es

*** School of Earth and Environmental Science, James Cook University, Townsville, QLD 4811, Australia; Tony.Kemp@jcu.edu.au

$\S$ Department of Earth and Environmental Sciences, Theresienstrasse 41 and Luisenstrasse 37, 80333 Munich, Germany; hegner@1mu.de

$\$ \$$ Instituto Superior Politécnico José Antonio Echeverria, Avenida 114 No 11901 entre 119 y 127, Marianao, codigo postal 19390, Habana, Cuba; mireya@civil.cujae.edu.cu

\$s\$ SHRIMP Center, Institute of Geology, Chinese Academy of Geological Sciences, 26 Baiwanzhuang Road, Beijing 100037, China; liudunyi@bjshrimp.cn

+ Corresponding author: Yamirka Rojas-Agramonte, Institut für Geowissenschaften, Universität Mainz, Becherweg 21, 55099 Mainz, Germany; e-mail: rojas@uni-mainz.de; Tel: +49 6131 3922164; Fax: +49 6131 3924769 
0.7039 which are typical for I-type granitoids. The chemistry of these rocks is compatible with arc-related granitoids typical of a subduction setting.

The zircon ages of this study constrain currently discussed geotectonic models and indicate that emplacement of the ophiolite mélange must be younger than $71 \mathrm{Ma}$. Based on current geodynamic models for the Caribbean, our data suggest that the oceanic crust in the northern ophiolite belt is of supra-subduction origin (probably fore-arc) related to a volcanic arc domain that formed during Late Cretaceous time. Apart from the granitoid sample from the Cerro el Chivo that was probably tectonically incorporated into the mélange, the remaining samples can be related to a pre-collision/ collision calc-alkaline subduction-related environment.

Key words: Central Cuba, Island arc, ophiolitic mélange, Sm-Nd-Hf isotopes, SHRIMP zircon dating

INTRODUCTION

Ophiolites occur in orogenic belts, either as intact complexes or as dismembered sequences or mélanges, and represent remnants of oceanic lithosphere that formed at mid-ocean ridges or in supra-subduction environments. According to Bloomer and others (1995) and Shervais (2001), many ophiolites appear to represent forearc basement, formed at the time of subduction initiation and tectonically emplaced when subduction zones are terminated by collision. Ophiolitic rocks are also important witnesses to subduction and plate tectonics because their formation requires seafloor spreading, and their emplacement requires plate convergence (Stern, 2004). Ophiolites and/or ophiolitic mélanges are either obducted onto continental margins during ocean closure and/or are tectonically incorporated into subduction-accretion complexes and exhumed in suture zones. Establishing the precise age and nature of exotic blocks within an ophiolite mélange or rocks which intrude a mélange or ophiolitic sequence is an important task in constraining the nature of accretion and collision.

Cuba, the largest island of the Greater Antilles (fig. 1), is characterized by a complex geological setting which mainly developed during Late Cretaceous convergence of the Caribbean and North American plates and Early Tertiary collision/ accretion processes. This led to closure of the proto-Caribbean ocean basin (or Atlantic Ocean), interruption of Cretaceous volcanic arc activity, and tectonic emplacement of ophiolites and serpentinitic mélanges during latest Cretaceous and early Tertiary times (Iturralde-Vinent, 1996, 1998; García-Casco and others, 2008b). Available geodynamic models for the region indicate that the proto-Caribbean oceanic crust, which correlates with central Atlantic oceanic lithosphere, formed in middle Late Jurassic to Late Cretaceous times during continental drift of North and South America (Pindell and others, 2005; Pindell and Kennan, 2009).

The northern ophiolitic belt is one of the most important features of the Cuban orogenic belt, extending for more than $1000 \mathrm{~km}$ along the island (fig. 1B). The ophiolite fragments and ophiolitic mélange are intimately associated and occur in tectonic contact with intra-oceanic arc sequences, although the relationship between these units is still uncertain (García-Casco and others, 2006; figs. 1B and 2). The island arc rocks are mainly developed to the south of the ophiolitic mélange, all along the island, and consist of a volcano-sedimentary sequence of mafic through felsic composition of Early Cretaceous island arc tholeiites and younger Albian to Campanian alkaline and high alkaline rocks (Diaz de Villalvilla, 1997).

Two main contrasting tectonic models have been proposed predicting different environments for the origin of the Cuban ophiolites and their relationship with the Cretaceous arc (fig. 3). Some models interpret the origin of Cuban ophiolites as remnants of Proto-Caribbean (Atlantic) oceanic lithosphere that formed at an ocean ridge after the break-up of Pangea in Jurassic times and in back arc basins related to NE-directed subduction of the Caribbean (Pacific) plate (Iturralde-Vinent, 1998, 2006; 

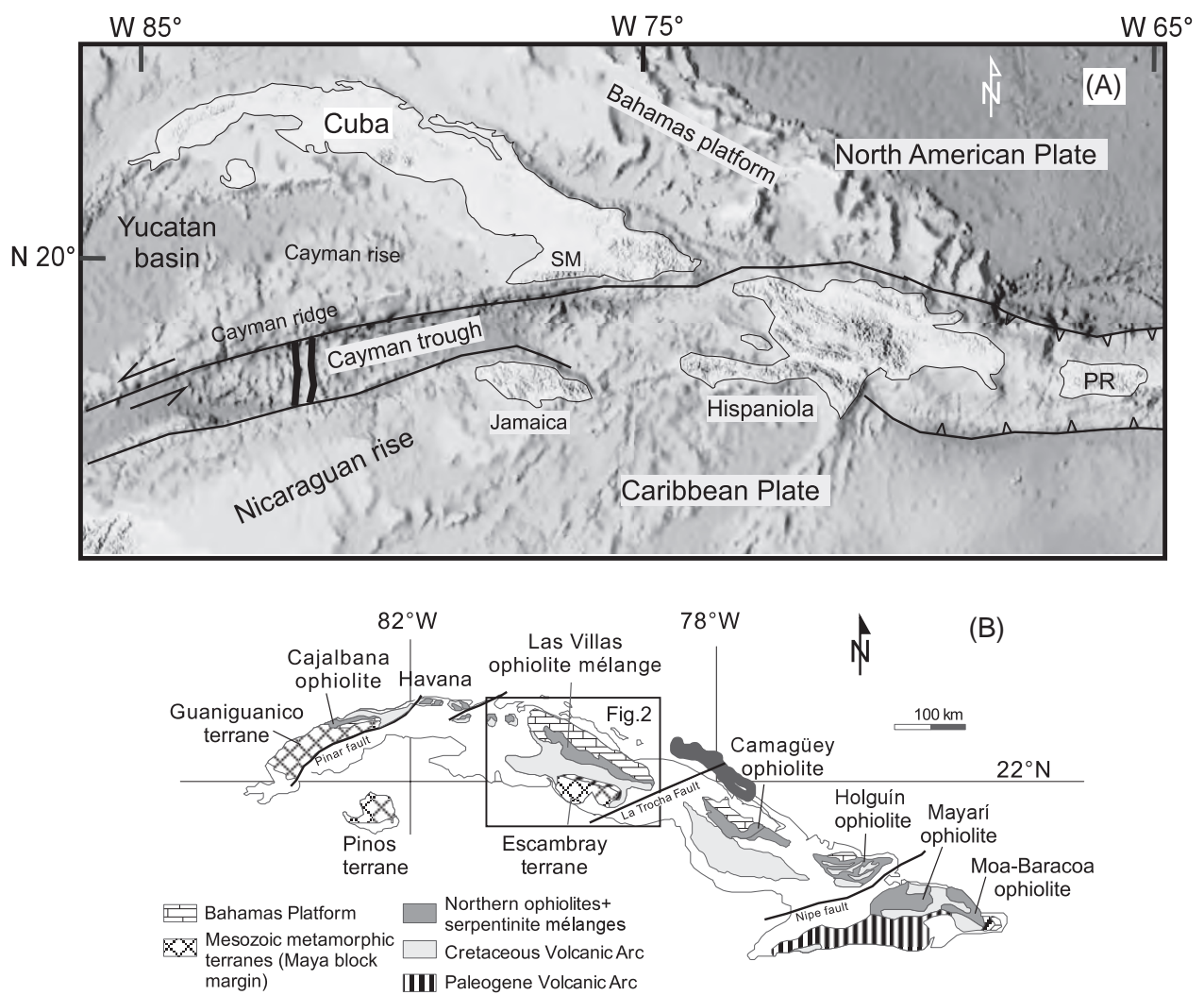

Fig. 1. (A) Portion of a bathymetric map of the NW Caribbean showing main features of the region (Greater Antilles; after Coastal \& Marine Geology Program: CMG InfoBank Atlas: Caribbean Sea region). Abbreviation: PR-Puerto Rico, SM-Sierra Maestra. (B) Simplified geological map of Cuba (after IturraldeVinent, 1996). Rectangle show location of figure 2.

fig. 3A). Other models favor Caribbean (Pacific) supra-subduction environments, including back-arc, fore-arc and arc settings, related to SW-directed subduction of the Proto-Caribbean lithosphere (fig. 3B; Andó and others, 1996; Proenza and others, 1999; García-Casco and others, 2008b). The earliest age of formation of the Cuban ophiolitic fragments is Late Jurassic (Tithonian)-Cretaceous (Albian-Cenomanian), based on paleontological dating of oceanic sediments that locally cover igneous rocks in several parts of the belt (Iturralde-Vinent, 1989; Llanes and others, 1998).

Felsic plutonic rocks, including diorites, quartz diorites, tonalites, trondjemites and oceanic plagiogranites associated with the ophiolites can be divided into four groups (Šarić and others, 2009): (1) oceanic plagiogranites and trondhjemites (Coleman and Peterman, 1975; Coleman and Donato, 1979); (2) pre-collisional calcalkaline to adakitic subduction-related rocks (for example, Li and Li, 2003; Kamei, 2004); (3) calc-alkaline and alkaline collision-related granitoids, associated with final emplacement of the ophiolites (for example, Brown and D'Lemos, 1991; Karsli and others, 2007); and 4) exotic blocks of granitoid rocks which were tectonically incorporated into a trench assemblage during subduction (for example, Cvetković and others, 2004). Whereas most studies on the Cuban ophiolites have focussed on the mafic parts of the ophiolitic assemblage (Proenza and others, 1999, 2003; Marchesi and others, 2006) and on high pressure (HP) blocks from associated serpentinite mélanges 


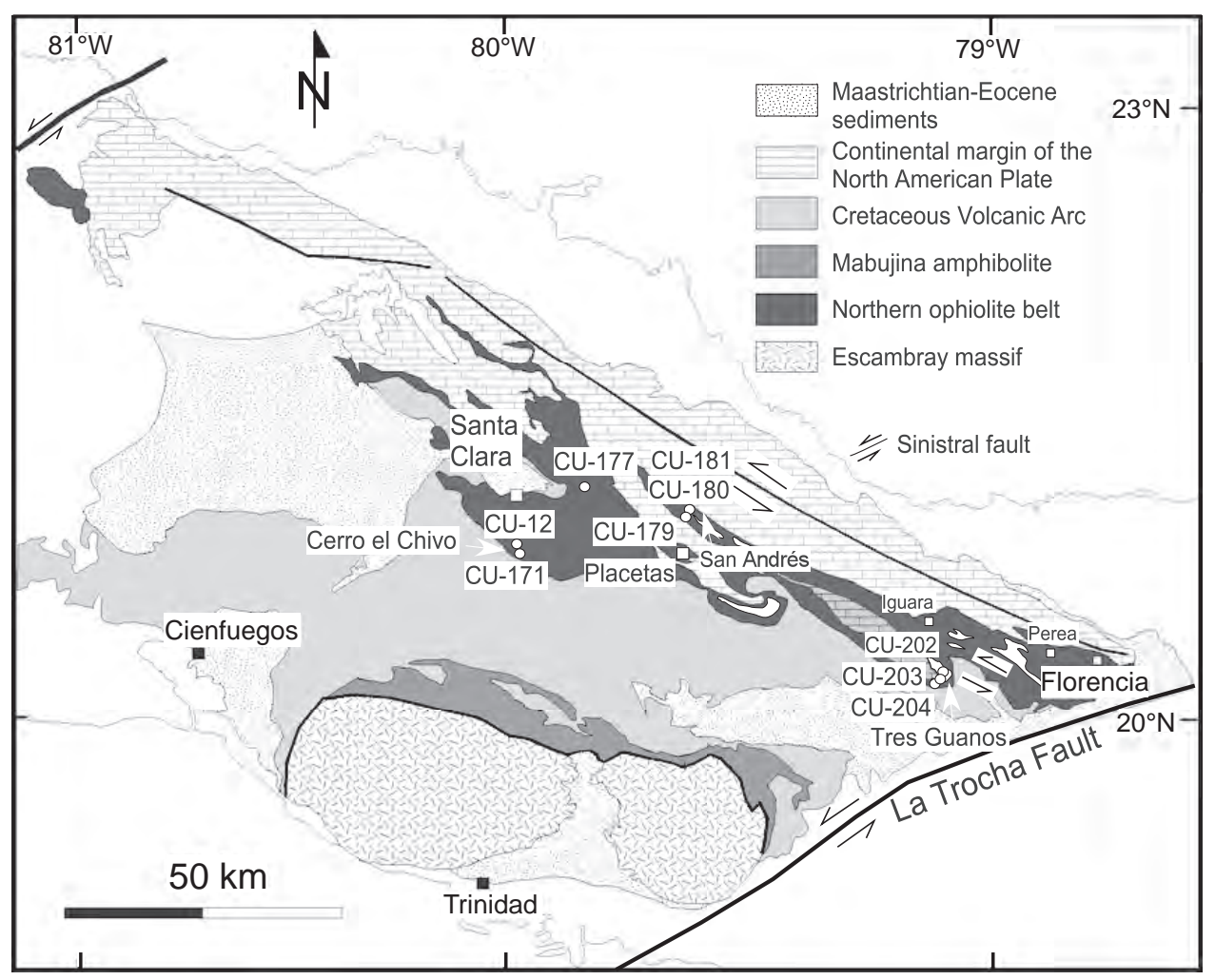

Fig. 2. Simplified geological map of central Cuba (after García-Delgado, 1998) showing location of dated samples.

representing the subduction channel (García-Casco and others, 2002, 2006, 2008a; Lázaro and García-Casco, 2008; Lázaro and others, 2009; Blanco and others, 2010), granitoid rocks associated with the ophiolites have received little attention.

We present and discuss geochronological, elemental and isotopic $\mathrm{Sm}-\mathrm{Nd}, \mathrm{Rb}-\mathrm{Sr}$ and Hf systematics for granitoid rocks which appear to intrude sections of the ophiolite sequences or occur as tectonic blocks within ophiolitic mélanges in central Cuba. These are the first combined isotopic data ever reported on such rocks in Cuba and the Caribbean and provide important constrains on the Late Cretaceous geodynamic setting of the central Cuban arc and ophiolitic complexes.

\section{GEOLOGICAL SETTING}

The Cuban island is representative of the Caribbean orogenic belt (fig. 1) which formed as a result of Late-Cretaceous-middle Eocene collision of the leading edge of the Caribbean plate with Caribeana, a hypothetical terrane consisting of a Mesozoic sedimentary pile (similar to a passive margin domain) located off the southeastern edge of the Maya block in Mexico (fig. 3B; García-Casco and others, 2001, 2008b), and with the continental margin of the Maya block and North America (Bahamas platform) (Iturralde-Vinent, 1996, 1998; Iturralde-Vinent and others, 2008). During this process the Cuban ophiolite bodies were sliced off from oceanic lithosphere, fractured and brecciated, and most can now be considered as tectonic mélanges with a serpentinite matrix which were thrust, north and northeastwards, onto the Mayan and Bahamian passive margins (North American plate). 

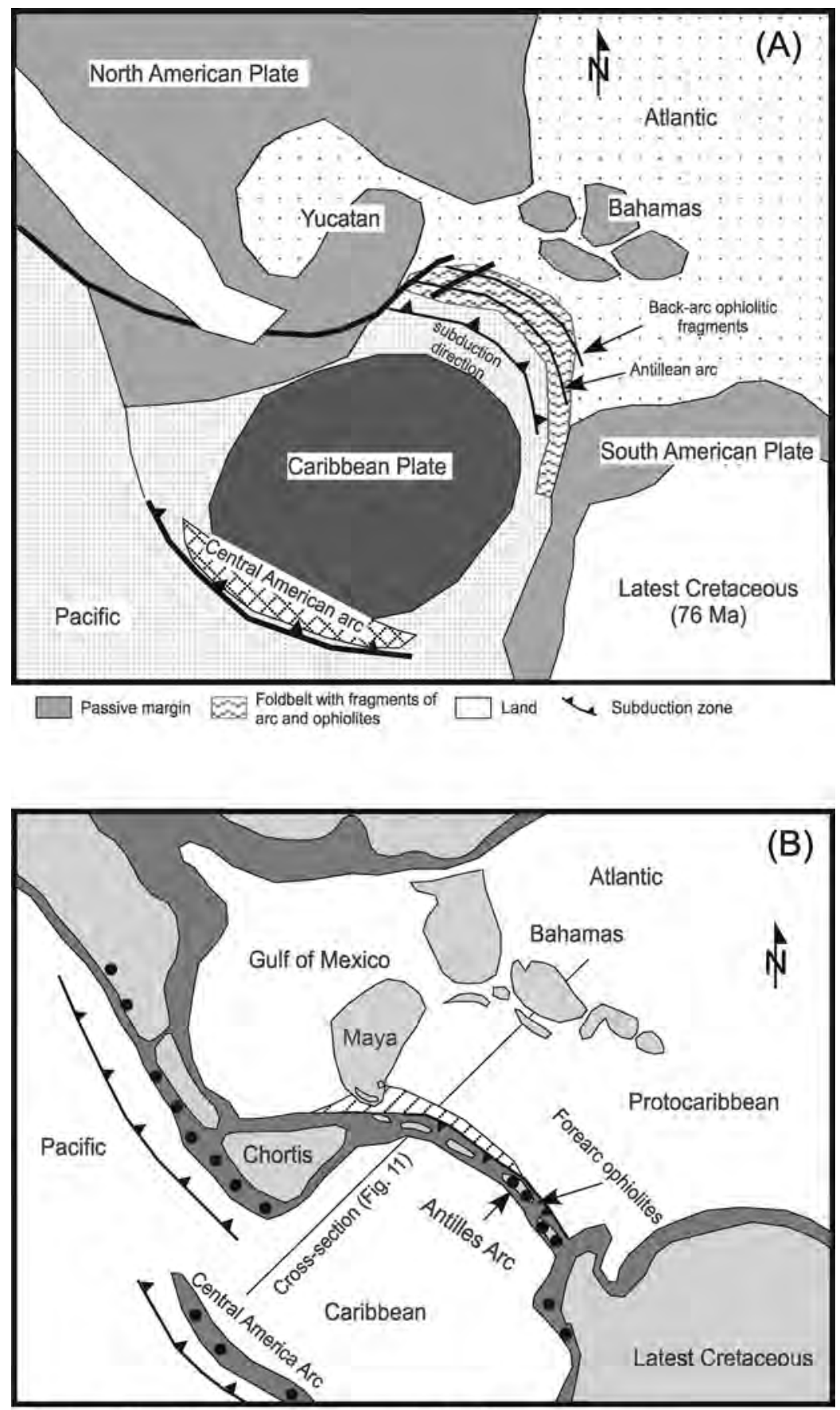

Lands $\square$ Shallow marine

Deep marine $[Z$ Caribeana $\bullet$ Island arc

Fig. 3. Two contrasting paleogeographic maps of the Caribbean region for the Latest Cretaceous. The main feature of these models is the positions of the subduction zones and therefore the origin of the ophiolites. (A) After Iturralde-Vinent $(1996,1998)$; according to this model the ophiolites formed in back arc basins related to NE-directed subduction of the Caribbean (Pacific) plate. (B) After García-Casco and others (2008); SW-directed subduction of the Proto-Caribbean lithosphere would favor a fore-arc environment (for example, the central Cuban ophiolitic fragments) related to SW-directed subduction of the Proto-Caribbean lithosphere. 
Several ophiolite bodies have been recognized from west to east, namely Cajálbana, Mariel-La Habana-Matanzas, Las Villas, Camagüey, Holguín, Mayarí and MoaBaracoa (fig. 1B; Iturralde-Vinent, 1996, 1998). The entire belt was previously considered to constitute a single geological entity, but it has recently been argued that the eastern Cuban complexes (Mayarí and Moa-Baracoa; fig. 1B) should not be included in the main belt because of the geological peculiarities of eastern Cuba (IturraldeVinent and others, 2006). Thus, whereas the ophiolitic bodies of central and western Cuba are overridden by Cretaceous volcanic arc sequences, the eastern ophiolite complexes override the Cretaceous volcanic arc sequences (Purial and Santo Domingo volcanics). In addition, the Cretaceous volcanic arc sequence of the El Purial Complex of eastern Cuba was metamorphosed to HP blueschist facies conditions, as opposed to volcanic arc sequences of central and western Cuba, and the HP rocks of serpentinite mélanges associated with ophiolitic complexes from eastern Cuba document a hot subduction scenario associated with the initiation of subduction of a young oceanic lithosphere or an oceanic ridge in Aptian times (García-Casco and others, 2008a; Lázaro and García-Casco, 2008; Lázaro and others, 2009). Proenza and others (1999) and Gervilla and others (2005) interpreted the eastern Cuba ophiolitic bodies as supra-subduction ophiolites which underwent melt infiltration of tholeiitic and boninitic composition.

In western and central Cuba, the northern ophiolitic belt went through a complex tectonic evolution involving different environments (fig. 1B). In western Cuba, basaltic rocks of the Cajalbana ophiolite reveal an island arc tholeiite (IAT) geochemical signature that suggests formation in a supra-subduction environment (García-Casco and others, 2003). This complex occurs as a northward-dipping sub-horizontal sheet, tectonically sandwiched between tectonic slices of two Cretaceous arc sequences, and the entire package overrode the Guaniguanico terrane northwards (Iturralde-Vinent, 1989, 1996). Basaltic rocks of the ophiolitic bodies in central Cuba (Las Villas region) have a calcalkaline signature and apparently also formed in a supra-subduction environment. The ophiolitic mélange in this region was thrust northwards and is locally imbricated with proto-Caribbean basin deposits (Placetas belt; García-Casco and others, 2008b; IturraldeVinent and others, 2008), whereas to the south of the mélange the arc rocks were tectonically emplaced above the ophiolite (fig. 2). The ophiolitic mélanges in the regions of Habana-Matanzas and Holguin are complexly tectonically imbricated with Cretaceous intra-oceanic volcanic arc rocks (Iturralde-Vinent, 1996, 1998).

A belt of arc-derived volcano-sedimentary rocks of Cretaceous age is widely developed all along Cuba and mostly occurs to the south of the ophiolite belt. In central Cuba, the arc has a consistent stratigraphy across strike, with oldest and deepest rocks in the south (including the Mabujina Amphibolite Complex) and younger rocks in the north. The Mabujina Complex has been interpreted as the metamorphosed root zone of the Cretaceous arc and its oceanic sole (Somin and Millán, 1981; Millán, 1996) or as a separate, older arc system (Blein and others, 2003). Both the Mabujina Complex and the Cretacous arc sequences were intruded by granitoid plutons ranging in age from $\sim 104$ to $81 \mathrm{Ma}$ (Rojas-Agramonte and others, 2006). Magmatic activity in the central Cuban arc terminated in latest Cretaceous (Campanian) time due to the collision/accretion process with North America (García-Casco and others, 2008b). This timing is supported by Ar-Ar ages from granitoids in the Camagüey region that indicate cooling and uplift between 70 and $75 \mathrm{Ma}$ (Hall and others, 2004). Sedimentary rocks of latest Campanian-Danian age unconformably overlie the deformed volcanic arc rocks (Iturralde-Vinent and others, 2008).

\section{The Northern Ophiolite Mélange (NOM) in Central Cuba}

The northern ophiolite mélange (NOM) in central Cuba (figs. 1B and 2) contains boulder- to tens of meters-size blocks of mostly chrysotile-lizardite serpentinite, anti- 
gorite $+/-$ lizardite and serpentinitic harzburgite and, less abundantly, pyroxenite, wehrlite and lherzolite. Fragments of ophiolitic crustal sections also occur, including ultramafic tectonites with layered and isotropic gabbros and associated cumulate rocks, chromite ores, diabase, basalt and pelagic sediments as well as exotic blocks of various sizes of eclogite, garnet amphibolite, blueschist, quartzite (recrystallized chert), metapelite, metabasite, metagabbro, and antigorite. Different types of intrusive granitoid rocks occur as blocks or cut the serpentinites and ophiolitic gabbros and diabases (Iturralde-Vinent, 1996; Millán, 1996; Kerr and others, 1999; García-Casco and others, 2006).

K-Ar ages for high-pressure blocks in central Cuba range from $\sim 130$ to $60 \mathrm{Ma}$ (Somin and Millán, 1981; Iturralde-Vinent and others, 1996) with most ages clustering around $\sim 110 \mathrm{Ma}$. This would suggest an Early Cretaceous age for subduction, with the younger ages probably representing resetting or cooling during Late CretaceousTertiary collisional processes and/or uplift (García-Casco and others, 2006). However, the whole-rock K-Ar technique is not an appropriate method to date high-pressure rocks, therefore these ages should be interpreted with caution because of the possibility of excess Ar, in which case some of these ages may be too old (McDougall and Harrison, 1999). Ar-Ar ages (amphibole and phengite) ranging from 123 to $103 \mathrm{Ma}$ and a $\mathrm{Rb}-\mathrm{Sr}$ isochron age (phengite-omphacite-whole rock) of $\sim 118 \mathrm{Ma}$ were reported by Schneider (2000; see also García-Casco and others, 2002, 2006) from an eclogite sample located north of the city of Santa Clara. According to these authors the eclogite block formed in a subduction system during pre-Aptian time and was later incorporated into a mélange which was then rapidly exhumed (Alpine-type) during AptianAlbian times. García-Casco and others (2003) provided geochemical evidence for a calc-alkaline signature in basaltic rocks from the Iguará-Perea region. An ${ }^{40} \mathrm{Ar} /{ }^{39} \mathrm{Ar}$ amphibole plateau age of $88 \pm 3.2 \mathrm{Ma}$ was obtained for a high-grade metagabbro indicating that the rocks from the Iguará-Perea region were metamorphosed in a Turonian-Coniacian volcanic arc environment (García-Casco and others, 2003). According to these authors the Iguará-Perea complex may represent the root zone of an embryonic or abandoned arc, based on geochemical similarities with the Mabujina Complex (fig. 2).

\section{Granitoids within the Northern Ophiolite Mélange in Central Cuba}

There are few studies on granitoids associated with the northern ophiolite mélange. These rocks occur as small to medium size linear bodies and dikes within the NOM (fig. 2) in the area south of Santa Clara (Cerro el Chivo area), to the N and NE of Santa Clara (Minerva Dam region), to the N and NE of Placetas (near San Ramón y San Andrés), and to the S of Iguará and Perea (Tres Guanos region). The morphology of these bodies is broadly concordant with the internal structure of the ophiolitic mélange (fig. 2). These rocks consist of diorite, quartz diorite, tonalite, plagiogranite and granodiorite and have been genetically linked to the island arc Manicaragua granitoids (Millán and Somin, 1985; Sukar and Pérez, 1988; Sukar and others, 1998) although the latter authors and Eguipko and others (1984) did not rule out a genetic link with the ophiolites. Sukar and others (2002) in particular suggested that these rocks formed in a supra-subduction zone environment, based on geochemical features and similarities with Semail and Troodos plagiogranites. According to Somin and Millán (1981) the occurrence of these granitoids proves that the NOM originally developed beneath the Cretaceous volcanic arc, and these authors considered the Tres Guanos granitoids to be part of a Late Jurassic(?)-Cretaceous ophiolite association. Renne and others (1989), on the other hand, argued that the Tres Guanos granitoids were compositionally distinct from typical ophiolitic plagiogranites. Iturralde-Vinent (1994, 1996) suggested that these granitoids may be derived from the root zone of a partially eroded Early Cretaceous remnant arc. 
Somin and Millán (1981) reported a whole-rock K-Ar age of 82 44 Ma for a layered metagabbro to the west of Perea and a K-Ar age of $70 \pm 5$ Ma for a quartz diorite sample which they related to the ophiolite. An arc-type quartz-diorite dike cutting ophiolitic diabase was described by Millán and Somin (1985) near Tres Guanos and has a K-Ar age of $88 \mathrm{Ma}$. K-Ar ages of $79 \pm 5 \mathrm{Ma}$ (whole-rock, Somin and Millan, 1981) and $61 \pm 1$ Ma on biotite (Meyerhoff and others, 1969) were reported for the Tres Guanos quartz monzonite, but Hatten and others $(1958,1988)$ indicated that this granitoid has a pre-Tithonian (pre-152 Ma; Palmer, 1983) intrusive age based on stratigraphic arguments and speculated that the K-Ar ages reflect a tectono-thermal overprint, presumably related to plate collision.

\section{SAMPLE DETAILS}

\section{Field Relationships and Sampling}

Samples from the ophiolitic mélange in central Cuba (fig. 2) were taken from isolated blocks within serpentinite or intruding gabbro and diabase of the ophiolitic sequence in the areas of Cerro el Chivo south of Santa Clara (CU12, CU171), the Minerva Dam NNE of Santa Clara (CU177), San Andrés north of Placetas (CU179, 180, 181), and Tres Guanos south of Iguará and Perea (CU202, 203, 204). On the 1: 250 000, Geological Map of Cuba (Pushcharovsky, 1988) these rocks appear as elongated bodies with a main ESE-WNW trend, concordant with the foliation of the ophiolites, although internally they are massive and not deformed.

Sample CU12 was collected from a ca. $1 \mathrm{~m}^{3}$ fresh block of undeformed trondhjemite lying near the road from Santa Clara to Manicaragua in the area of Cerro El Chivo, close to the National Highway (N22 $20^{\prime} 00.0^{\prime \prime}$, W79 $57^{\prime} 30.0^{\prime \prime}$; fig. 2). Undeformed trondhjemite sample CU171 also comes from the area of Cerro el Chivo (N22 20'27.0', W79 $57^{\prime} 36.9^{\prime \prime}$, fig. 2) and occurs together with blocks of gabbro within serpentinitic mélange. Regional descriptions of the mélange from the Cerro el Chivo hills mention plagiogranite fragments tectonically enclosed in a strongly deformed serpentinite matrix (Millán and Somin, 1985). Slightly weathered sample CU177 was taken from an exposure on the road from Manayabo settlement to Minerva Dam (N22 $24^{\prime} 12.4^{\prime \prime}$, W79 $48^{\prime} 44.1^{\prime \prime}$, fig. 2). The rock has a faint foliation, and the primary texture is preserved. Three samples were obtained from the San Andrés granitoids of the Las Bocas Group; tonalite CU179 was collected near the San Andres River close to the Centro de Acopio Rodriguez (N22 $21^{\prime} 40.1^{\prime \prime}$, W79 $38^{\prime} 41.1^{\prime \prime}$, fig. 2). This undeformed rock occurs as a block together with ultramafic fragments. Sample CU180 intrudes sample CU181, and both were collected close to sample CU179 (N22 21'53.5", W79 $38^{\prime} 27.9^{\prime \prime}$, fig. 2) and are also undeformed.

Three more samples were collected from the so-called Tres Guanos "quartz monzonite" body (Somin and Millán, 1981). These rocks are exposed in an antiformal structure with rocks of the Placetas belt in tectonic contact with intrusive rocks in the core. The granitoids also occur in tectonic contact with the serpentinite matrix and ultramafic rocks that surround the core of the antiform. Our fresh and unfoliated sample CU202 was collected at the bridge over the Las Manzanas stream on a minor road from Tres Guanos to Manacas village (fig. 2, N22 $07^{\prime} 09.8^{\prime \prime}$, W79 $13^{\prime} 30.5^{\prime \prime}$ ). Sample tonalite CU203 and trondhjemite CU204 were collected close to the Manacas stream (fig. 2, N22 $06^{\prime} 38.1^{\prime \prime}, \mathrm{W} 79^{\circ} 14^{\prime} 06.2^{\prime \prime}$ ). Both samples are fresh and unfoliated but field relationships are not clear, although in nearby outcrops we observed granitoids in tectonic contact with serpentinite.

\section{Petrography of Dated Samples}

Trondhjemite sample CU12 is a gray-greenish to light gray, medium- to coarsegrained and partly cataclastic rock. The texture is hypidiomorphic granular with 
porphyroclastic plagioclase. The rock consists of zoned, partly seriticized plagioclase, quartz and hornblende that is almost completely altered into tremolite actinolite. Granite sample CU177 has a fine- to medium-grained groundmass of plagioclase, quartz and well oriented, partly chloritized hornblende laths with rare, larger plagioclase phenocrysts that are partly seriticized. Tonalite sample CU180 displays a wellpreserved igneous texture and consists of large, twinned and partly zoned and variably seriticized plagioclase and large hornblende laths or needles that are partly chloritized. These are set in a fine-grained groundmass of quartz and plagioclase. Some quartz aggregates have slightly undulose extinction. Granite sample CU181 is mediumgrained with spectacular, large zoned and twinned plagioclase grains whose cores are partly seriticized. In addition there is undulose quartz and minor hornblende. The thin section reveals serrated grain boundaries and a cataclastic fabric with many broken grain fragments. Trondhjemite sample CU202 exhibits a well-preserved mediumgrained igneous fabric with idiomorphic, zoned and twinned plagioclase whose cores are commonly seriticized. Quartz is mainly undulose, and minor biotite flakes are partly chloritized. Trondhjemite sample CU204 has a fine-grained groundmass of quartz and plagioclase with idiomorphic, partly zoned plagioclase phenocrysts and rare needles of hornblende and minor epidote. In most samples the mafic minerals are dominated by hornblende, which is characteristic of I-type and ocean island arc granitoids (for example, Chappell and White, 1974).

\section{RESULTS}

\section{Geochemical Data}

The major and trace element contents of the granitoid rocks from the Cuban ophiolite mélange are presented in table 1 and plotted in figs. 4, 5 and 6 . According to petrographic inspection of thin sections, the samples are relatively fresh to slightly altered. This observation is confirmed by the low to moderate loss-on-ignition (LOI) values of 0.9 to 2.2 weight percent (table 1). The chemical effects of alteration, that is, variable mobilization of $\mathrm{CaO}, \mathrm{MgO}$, alkali elements $(\mathrm{Na}, \mathrm{K})$ and large ion lithophile elements (LILE) such as Rb, Ba, and $\mathrm{Sr}$ (Staudigel and others, 2003), were not observed in the samples.

The samples are metaluminous (with molecular ratios [mol. A/NK] between 1 and 2) to weakly peraluminous (fig. 4; Shand, 1943). They have $\mathrm{SiO}_{2}$ concentrations of 50 to 74 weight percent and are low to medium in $\mathrm{K}_{2} \mathrm{O}(0.2-2.5$ wt. \%) concentrations. Their $\mathrm{Al}_{2} \mathrm{O}_{3}$ and $\mathrm{Rb}$ contents $\left(\mathrm{Al}_{2} \mathrm{O}_{3}=14.2-17.2, \mathrm{Rb}=7.5-40 \mathrm{ppm}\right)$ are slightly higher than in typical oceanic plagiogranites. Harker diagrams (not shown) reveal good linear correlation between silica, alumina and magnesia and, to some extent, total iron, as can be expected in a magmatic differentiation trend. The ternary normative feldspar diagram of Barker (1979) predominantly classifies the granitoids as trondhjemite with three samples of tonalitic composition (CU203, 179 and 180) and one with granitic composition (CU181; fig. 5). The AFM diagram (not shown), although developed for volcanic rocks (Irvine and Baragar, 1971), exhibits a clear calc-alkaline trend with tonalite sample CU203 plotting close to the calc-alkaline/ tholeiite division.

Trace element discrimination diagrams for granitoid rocks (Pearce and others, 1984) show the dated samples to have volcanic arc affinity (fig. 6). Multi-element and rare earth element (REE) patterns normalized to ocean ridge granitic rock (Pearce and others, 1984) show high LILE/HFSE ratios, moderate Rb, Th, and U enrichment, and slight depletion in LREE and strong depletion in HREE (fig. 7A). All these features are characteristic of I-type granitoids (Chappell and White, 1974) and are commonly found in supra-subduction zone settings (Miyashiro, 1973; Pearce and others, 1984; Metcalf and Shervais, 2008). Tonalite sample CU-203 deviates from this 
TABLE 1

Chemical analyses of granitoids from the northern ophiolitic mélange*

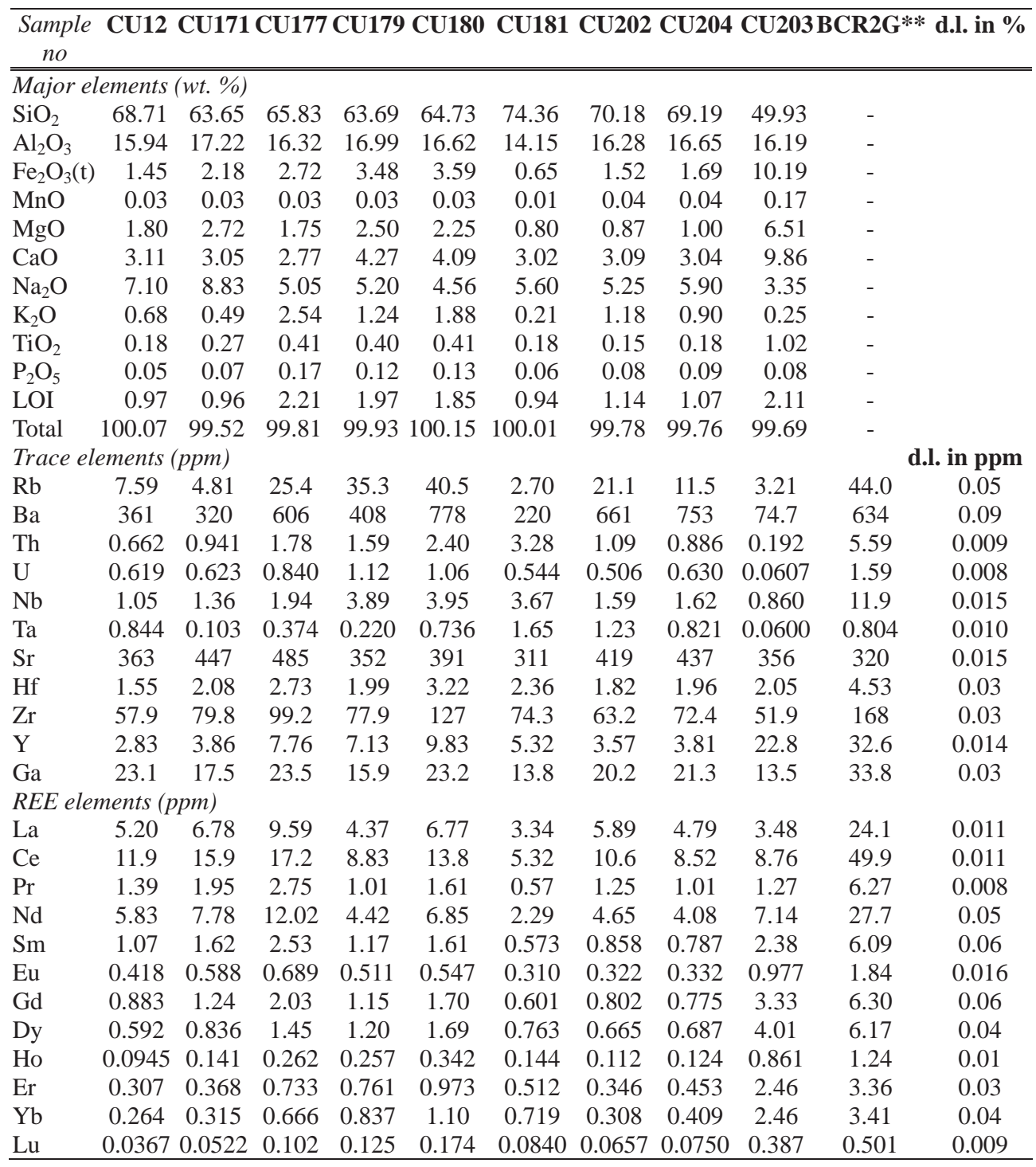

* Major elements measured by XRF; trace elements determined by ICP-MS, see Analytical Procedures section.

** USGS geochemical reference standard.

d.1.- detection limit

composition with slightly enriched REE and a flat pattern. A slight positive Eu-anomaly in some samples (fig. 7B) suggests that these rocks contain cumulate plagioclase.

\section{Zircon Geochronology and Hafnium Isotopic Systematics}

The zircons of trondhjemite sample CU12 are clear, almost exclusively longprismatic, perfectly euhedral and display well developed oscillatory magmatic zoning under cathodoluminenscence (CL) (fig. 8A, inset). Nine grains were analyzed on 


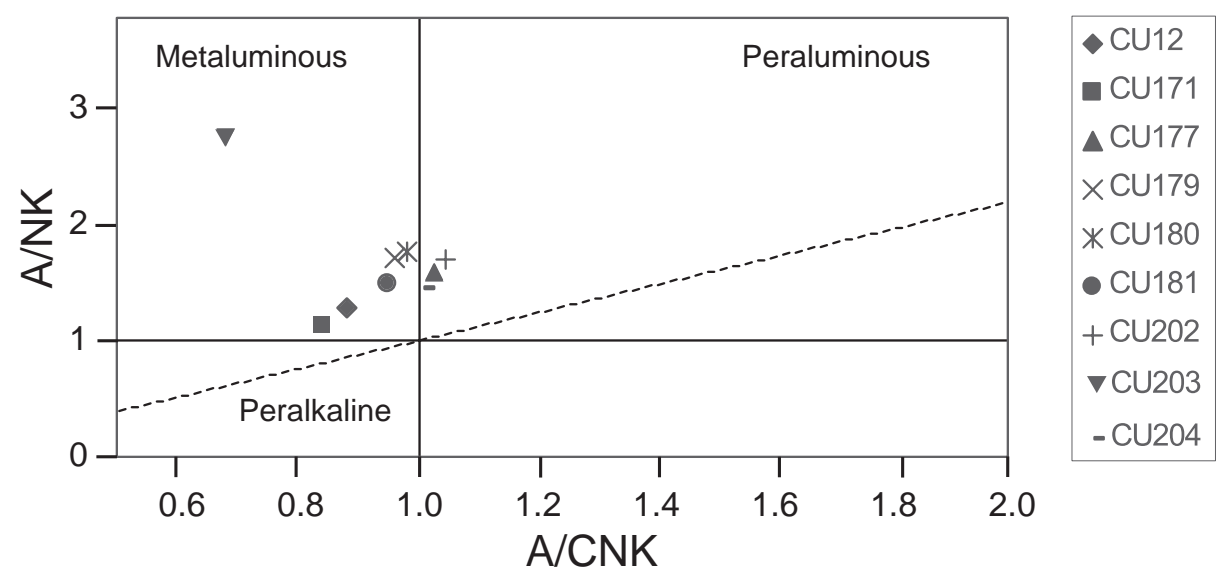

Fig. 4. Classic $\mathrm{A} / \mathrm{NK}\left(\mathrm{Al}_{2} \mathrm{O}_{3} /\left(\mathrm{Na}_{2} \mathrm{O}+\mathrm{K}_{2} \mathrm{O}\right)\right.$ vs. $\mathrm{A} / \mathrm{CNK}\left(\mathrm{Al}_{2} \mathrm{O}_{3} /\left(\mathrm{CaO}+\mathrm{Na}_{2} \mathrm{O}+\mathrm{K}_{2} \mathrm{O}\right)\right.$ plot of Shand (1943) discriminating metaluminous, peraluminous and peralkaline compositions.

SHRIMP II (see Analytical Procedures section), and the concordant data are well grouped, providing a precise mean ${ }^{206} \mathrm{~Pb} /{ }^{238} \mathrm{U}$ age of $85.9 \pm 0.6 \mathrm{Ma}$ (fig. $8 \mathrm{~A}$ ), which is interpreted as the crystallization age of the trondhjemite. Grain 12.3 had rather low ion count rates and therefore yielded imprecise isotopic ratios (table 2; fig. 8A), but the ${ }^{206} \mathrm{~Pb} /{ }^{238} \mathrm{U}$ age is identical to the other results. Zircons of granite sample CU181 are clear, mostly euhedral and long-prismatic, with excellent striped, planar as well as

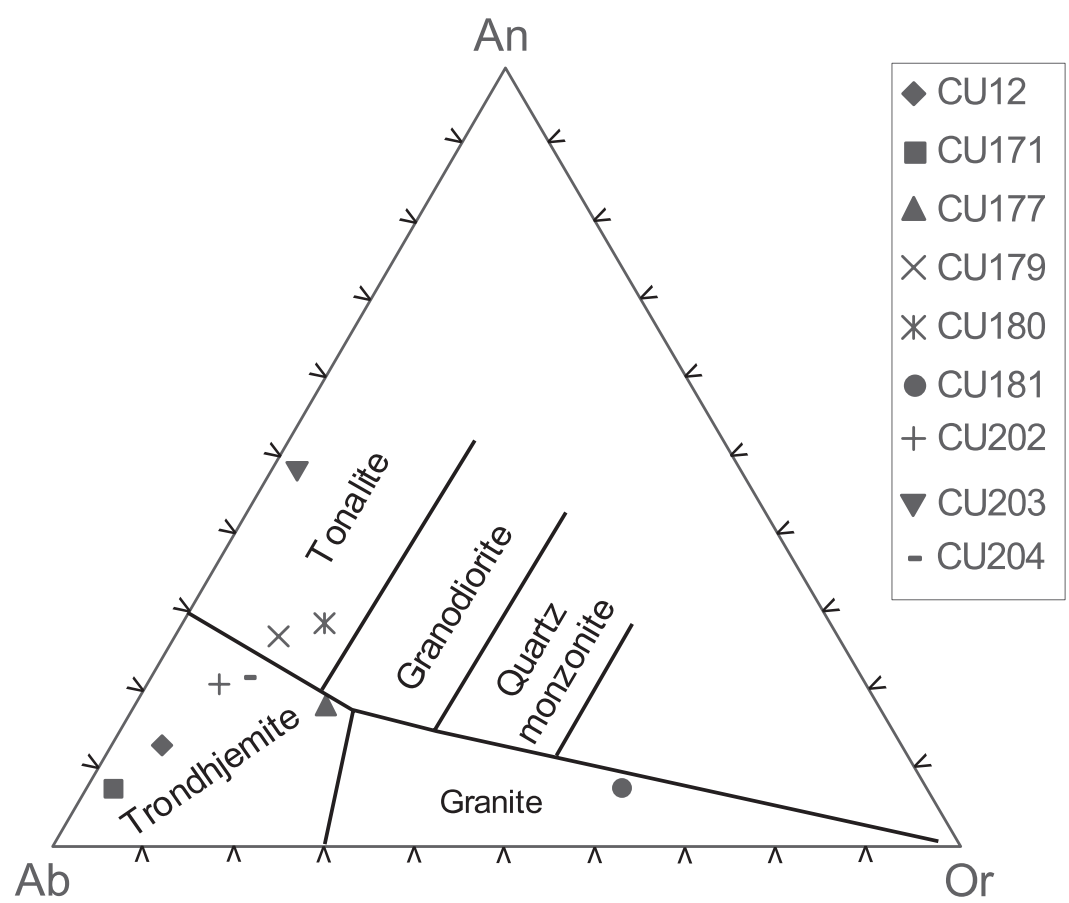

Fig. 5. Ternary normative feldspar diagram (Ab-An-Or; Barker, 1979). 


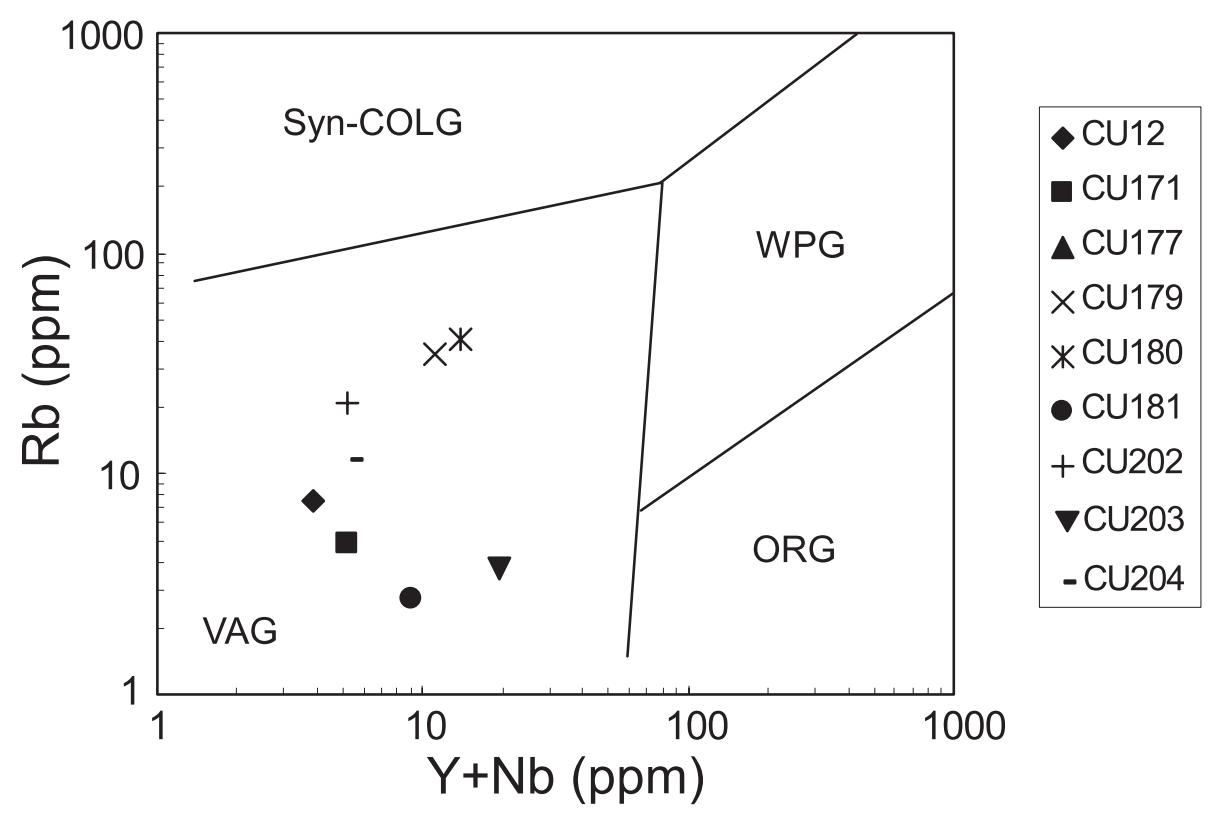

Fig. 6. Rb vs. (Y/Nb) discrimination diagram for granitoid rocks within the northern ophiolite mélange (Pearce and others, 1984). VAG—volcanic arc granite, Syn-COLG-syn-collisional granite, ORG-ocean ridge granite, WPG-within plate granite.

oscillatory magmatic zoning (fig. $8 \mathrm{~B}$, inset). Some grains have very narrow dark (high-U) rims that are too thin to be analyzed on SHRIMP. Seven grains provided consistent and concordant results with a precise mean ${ }^{206} \mathrm{~Pb} /{ }^{238} \mathrm{U}$ age of $76.3 \pm 0.5 \mathrm{Ma}$ (fig. 8B), which we interpret to reflect granite crystallization. The zircons of trondhjemite sample CU204 define an homogeneous population of clear, long-prismatic, perfectly euhedral grains with well-developed oscillatory zoning (fig. 8C, insets). Some grains have cores with planar zoning and oscillatory-zoned rims. Nine grains were analyzed of which eight provided concordant data points with a precise mean ${ }^{206} \mathrm{~Pb} /$ ${ }^{238} \mathrm{U}$ age of $76.6 \pm 0.4 \mathrm{Ma}$ (fig. $8 \mathrm{C}$ and inset). One grain, morphologically indistinguishable from the others, yielded a significantly older, concordant age of 268.0 $\pm 1.4 \mathrm{Ma}$ (fig. 8C), which, we interpret as an inherited xenocryst.

Tonalite sample CU180 also contains clear, mostly euhedral and long-prismatic zircons with narrow to wide oscillatory as well as striped, planar magmatic zoning (fig. 8D, inset) of magmatic origin (for example, Corfu and others, 2003, figs. 4-17), rather similar to the CL images of zircons from CU181. Seven grains were analyzed and provided identical and concordant ${ }^{206} \mathrm{~Pb} /{ }^{238} \mathrm{U}$ ratios with a mean age of $74.8 \pm 0.7 \mathrm{Ma}$ (fig. 8D). Again, we interpret this as reflecting the time of tonalite crystallization. Trondhjemite sample CU202 contains an homogeneous population of clear, longprismatic, perfectly euhedral grains with well-developed oscillatory zoning (fig. 8E, small insets). As in sample CU204, some grains have cores of planar zoning with oscillatory-zoned rims, but these are not inherited core-rim relationships, but probably reflect slow initial zircon growth, followed by fast growth during magma cooling. Eight morphologically similar grains were analyzed of which seven provided identical and concordant ${ }^{206} \mathrm{~Pb} /{ }^{238} \mathrm{U}$ ratios with a precise mean age of $71.1 \pm 0.4 \mathrm{Ma}$ (fig. $8 \mathrm{E}$ and inset). The analysis of grain 7 yielded poor ion count rates and is therefore less precise but gave an otherwise identical result. One additional grain with a concordant analysis 

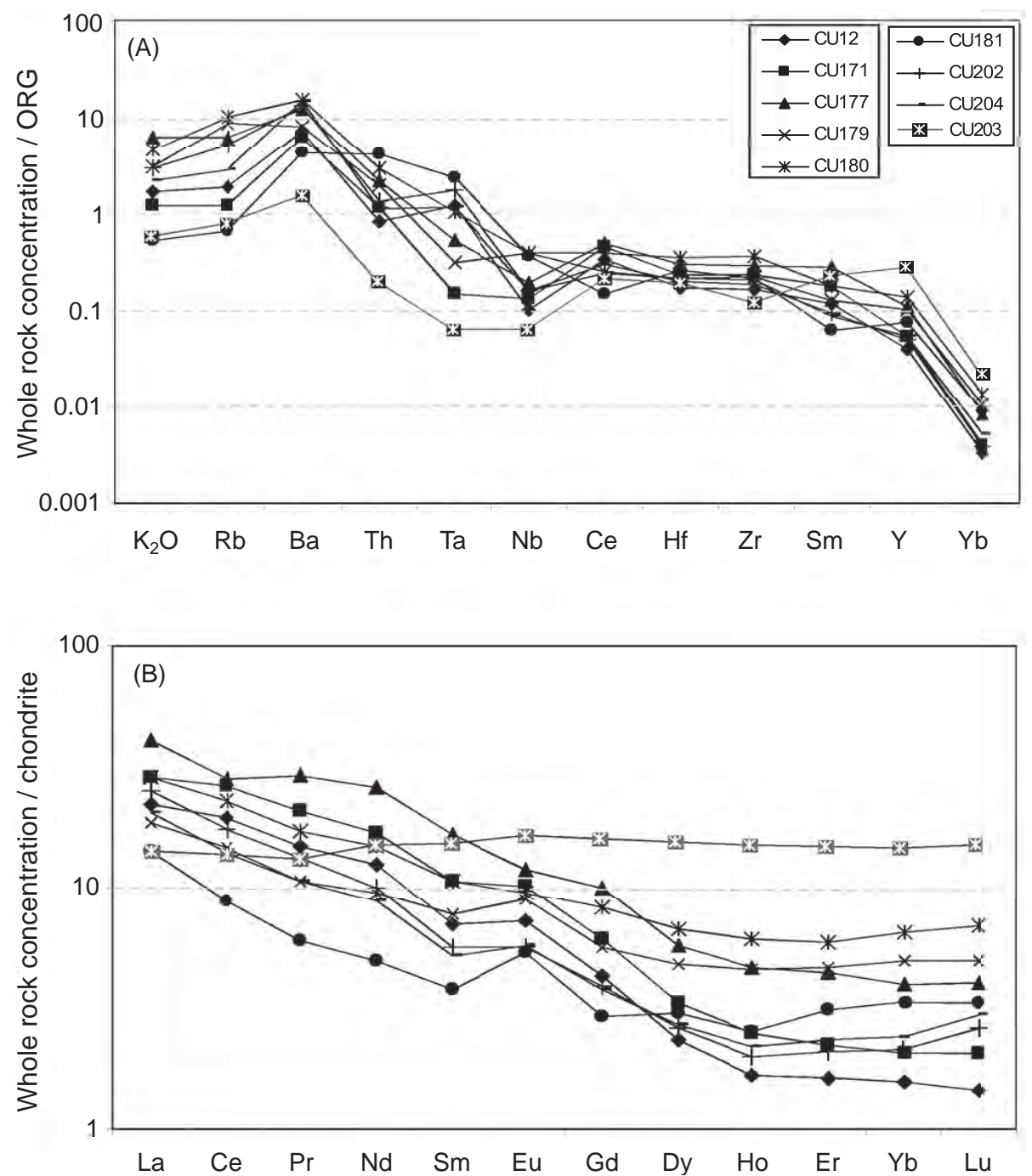

Fig. 7. (A) Ocean ridge granite (ORG) normalized trace element patterns of granitoids associated with the central Cuban ophiolitic mélange. Normalizing values from Pearce and others (1984). (B) Chondritenormalized REE patterns, symbols as in (A). Normalizing values from Sun and McDonough (1989).

yielded a significantly older ${ }^{206} \mathrm{~Pb} /{ }^{238} \mathrm{U}$ age of $536 \pm 3 \mathrm{Ma}$ (fig. $8 \mathrm{E}$ ) and is interpreted as an inherited xenocryst.

The initial $\varepsilon_{\mathrm{Hf}}$ values of two zircon grains of the 71 Ma population from sample CU202 are identical at 12.8 and 12.1 respectively (table 3, fig. 9A) and suggest derivation of the host magmas from a juvenile, depleted source. Grain CU202-1 with a zircon age of $536 \mathrm{Ma}$ yielded a lower $\varepsilon_{\mathrm{Hf}}(\mathrm{t})$-value of 5.7 suggesting crystallization in an early Cambrian protolith that was derived from the depleted upper mantle. The Maya block may represent a possible source for this xenocryst as it yielded similar ages (Weber and others, 2006; Nance and others, 2007).

The $\varepsilon_{\mathrm{Hf}(\mathrm{t})}$ values of two zircon grains of the 77 Ma population from sample CU204 are almost identical at 12.0 and 12.6 (table 3, fig. 9A) and, as in sample CU202, suggest 

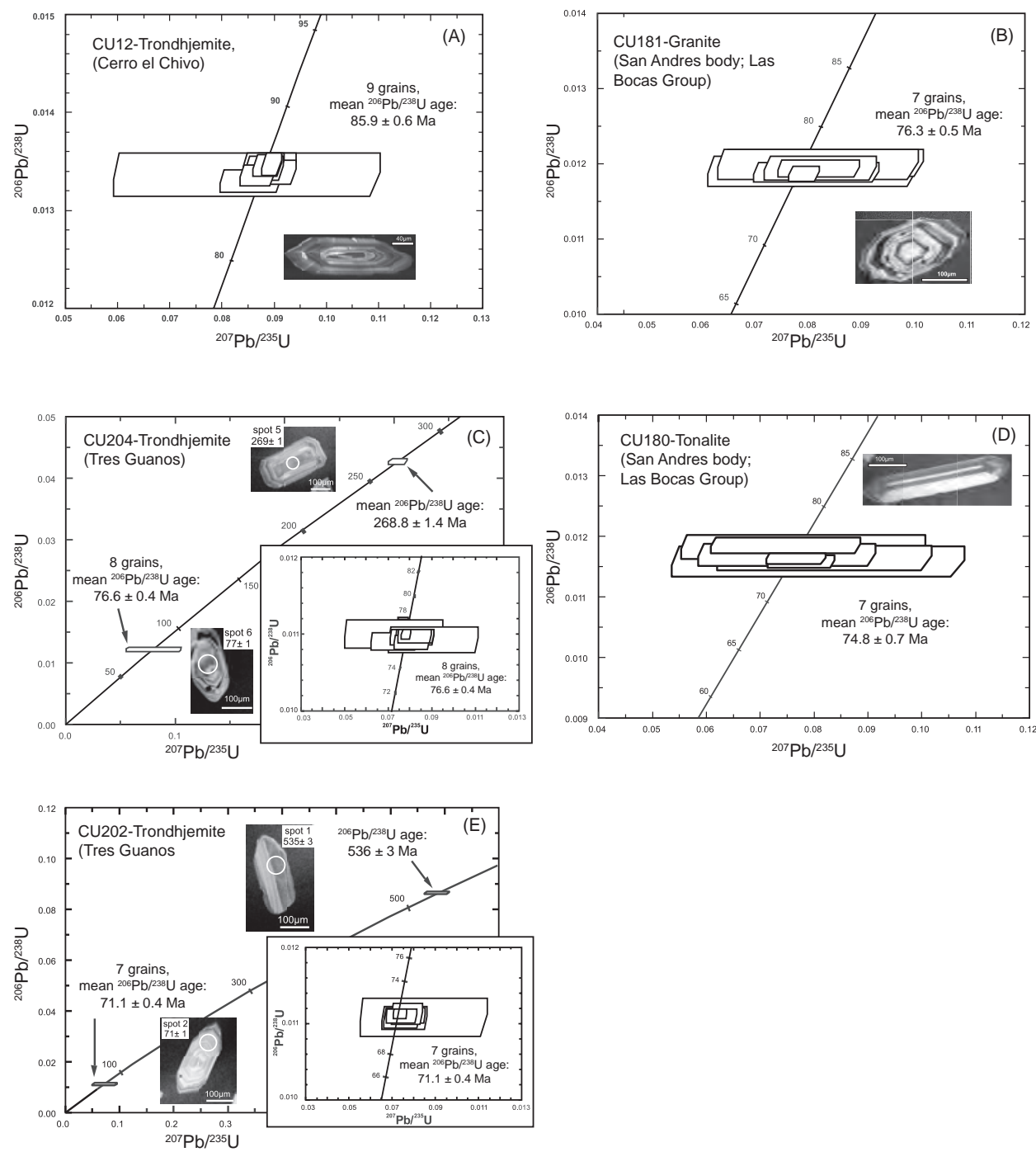

Fig. 8. Concordia diagrams (A-E) showing SHRIMP analyses of zircons from central Cuba granitoids associated with the NOM.

crystallization of the zircons from a juvenile depleted source. Grain CU204-5 with a zircon age of $268 \mathrm{Ma}$ yielded a significantly lower $\varepsilon_{\mathrm{Hf}(\mathrm{t})}$ of -2.4 suggesting crystallization in an early Triassic continental protolith with a significant crustal history. A Permo-Triassic continental arc in eastern Mexico (Torres and others, 1999) could have been the source of this inherited zircon.

\section{Whole-rock Nd and Sr Isotopic Composition}

The initial $\mathrm{Nd}$ and $\mathrm{Sr}$ isotopic compositions were calculated with the mean zircon age for four of the granitoids (table 4 ). The high initial $\varepsilon_{\mathrm{Nd}(\mathrm{t})}$ values for sample CU204 of 7.3 to 7.7 (fig. 9A) are indistinguishable within analytical error and indicate a crustal protolith derived from a highly depleted upper mantle. In contrast, sample CU202 
TABLE 2

SHRIMP II analytical data for spot analyses of single zircons from granitoids in the northern ophiolite mélange, central Cuba

\begin{tabular}{|c|c|c|c|c|c|c|c|c|}
\hline Sample No. & $\begin{array}{c}\mathrm{U} \\
(\mathrm{ppm})\end{array}$ & $\begin{array}{c}\text { Th } \\
\text { (ppm) }\end{array}$ & $\frac{{ }^{206} \mathrm{~Pb}}{{ }^{204} \mathrm{~Pb}}$ & $\frac{{ }^{208} \mathrm{~Pb}^{*}}{{ }^{206} \mathrm{~Pb}^{*}}$ & $\frac{{ }^{207} \mathrm{~Pb}^{*}}{{ }^{206} \mathrm{~Pb}^{*}}$ & $\frac{{ }^{206} \mathrm{~Pb}}{{ }^{238} \mathrm{U}}$ & $\frac{{ }^{207} \mathrm{~Pb}^{*}}{{ }^{235} \mathrm{U}}$ & $\begin{array}{c}\frac{{ }^{206} \mathrm{~Pb}^{*}}{{ }^{238} \mathrm{U}} \\
\text { age }(\mathrm{Ma}) \pm 1 \sigma\end{array}$ \\
\hline \multicolumn{9}{|l|}{ CU12 } \\
\hline CU12-1.1 & 243 & 107 & 13590 & $0.1318 \pm 79$ & $0.0467 \pm 31$ & $0.01330 \pm 13$ & $0.086 \pm 59$ & $85 \pm 1$ \\
\hline CU12-2.1 & 235 & 48 & 71271 & $0.0596 \pm 40$ & $0.0490 \pm 20$ & $0.01340 \pm 12$ & $0.090 \pm 40$ & $86 \pm 1$ \\
\hline CU12-3.1 & 245 & 78 & 1795 & $0.082 \pm 32$ & $0.0461 \pm 14$ & $0.01337 \pm 23$ & $0.085 \pm 257$ & $86 \pm 1$ \\
\hline CU12-4.1 & 264 & 105 & 59984 & $0.1212 \pm 51$ & $0.0476 \pm 19$ & $0.01343 \pm 12$ & $0.088 \pm 37$ & $86 \pm 1$ \\
\hline CU12-5.1 & 450 & 132 & 170155 & $0.0919 \pm 32$ & $0.0479 \pm 14$ & $0.01346 \pm 12$ & $0.089 \pm 27$ & $86 \pm 1$ \\
\hline CU12-6.1 & 1007 & 341 & 8373 & $0.1016 \pm 48$ & $0.0474 \pm 20$ & $0.01348 \pm 12$ & $0.088 \pm 40$ & $86 \pm 1$ \\
\hline CU12-7.1 & 596 & 294 & 25414 & $0.1485 \pm 51$ & $0.0486 \pm 21$ & $0.01348 \pm 11$ & $0.090 \pm 40$ & $86 \pm 1$ \\
\hline CU12-8.1 & 885 & 338 & 32898 & $0.1211 \pm 42$ & $0.0472 \pm 17$ & $0.01337 \pm 11$ & $0.087 \pm 34$ & $86 \pm 1$ \\
\hline CU12-9.1 & 908 & 311 & 130378 & $0.1166 \pm 23$ & $0.0483 \pm 9$ & $0.01347 \pm 11$ & $0.090 \pm 19$ & $86 \pm 1$ \\
\hline \multicolumn{9}{|l|}{ CU181 } \\
\hline CU181-1 & 288 & 144 & 2556 & $0.177 \pm 12$ & $0.0496 \pm 48$ & $0.0119 \pm 1$ & $0.082 \pm 8$ & $76 \pm 1$ \\
\hline CU181-2 & 230 & 107 & 1000000 & $0.1704 \pm 74$ & $0.0482 \pm 23$ & $0.0119 \pm 1$ & $0.079 \pm 4$ & $76 \pm 1$ \\
\hline CU181-3 & 243 & 114 & 1701 & $0.173 \pm 18$ & $0.0495 \pm 73$ & $0.0119 \pm 1$ & $0.081 \pm 12$ & $76 \pm 1$ \\
\hline CU181-4 & 122 & 33 & 953 & $0.096 \pm 28$ & $0.049 \pm 12$ & $0.0119 \pm 2$ & $0.080 \pm 20$ & $76 \pm 1$ \\
\hline CU181-5 & 161 & 66 & 820 & $0.158 \pm 28$ & $0.050 \pm 12$ & $0.0120 \pm 2$ & $0.082 \pm 19$ & $77 \pm 1$ \\
\hline CU181-6 & 129 & 58 & 519 & $0.141 \pm 26$ & $0.049 \pm 11$ & $0.0120 \pm 2$ & $0.081 \pm 19$ & $77 \pm 1$ \\
\hline CU181-7 & 235 & 109 & 1227 & $0.160 \pm 15$ & $0.0498 \pm 63$ & $0.0119 \pm 2$ & $0.082 \pm 11$ & $76 \pm 1$ \\
\hline \multicolumn{9}{|l|}{ CU204 } \\
\hline CU204-1 & 1663 & 376 & 20546 & $0.0754 \pm 26$ & $0.0473 \pm 12$ & $0.0120 \pm 1$ & $0.078 \pm 2$ & $77 \pm 0.42$ \\
\hline CU204-2 & 347 & 148 & 1543 & $0.1374 \pm 153$ & $0.0442 \pm 63$ & $0.0119 \pm 1$ & $0.073 \pm 10$ & $76 \pm 1$ \\
\hline CU204-3 & 211 & 58 & 1812 & $0.1133 \pm 291$ & $0.0552 \pm 125$ & $0.0119 \pm 2$ & $0.091 \pm 21$ & $76 \pm 1$ \\
\hline CU204-4 & 179 & 57 & 600 & $0.0579 \pm 315$ & $0.0439 \pm 136$ & $0.0120 \pm 2$ & $0.073 \pm 23$ & $77 \pm 1$ \\
\hline CU204-5 & 1799 & 873 & 12225 & $0.1480 \pm 17$ & $0.0517 \pm 6$ & $0.0426 \pm 2$ & $0.304 \pm 4$ & $269 \pm 1$ \\
\hline CU204-6 & 269 & 86 & 2724 & $0.1000 \pm 109$ & $0.0497 \pm 46$ & $0.0120 \pm 1$ & $0.082 \pm 8$ & $77 \pm 1$ \\
\hline CU204-7 & 371 & 113 & 1240 & $0.1050 \pm 141$ & $0.0490 \pm 60$ & $0.0120 \pm 1$ & $0.081 \pm 10$ & $77 \pm 1$ \\
\hline CU204-8.1 & 343 & 92 & 2065 & $0.0878 \pm 112$ & $0.0493 \pm 48$ & $0.0119 \pm 1$ & $0.081 \pm 8$ & $76 \pm 1$ \\
\hline CU204-8.2 & 253 & 64 & 3367 & $0.0945 \pm 121$ & $0.0498 \pm 52$ & $0.0120 \pm 1$ & $0.082 \pm 9$ & $77 \pm 1$ \\
\hline \multicolumn{9}{|l|}{ CU180 } \\
\hline CU180-1 & 350 & 173 & 5013 & $0.1536 \pm 93$ & $0.0478 \pm 36$ & $0.0116 \pm 1$ & $0.077 \pm 6$ & $75 \pm 1$ \\
\hline CU180-2 & 129 & 57 & 864 & $0.201 \pm 34$ & $0.048 \pm 14$ & $0.0118 \pm 2$ & $0.078 \pm 23$ & $76 \pm 1$ \\
\hline CU180-3 & 221 & 113 & 4701 & $0.191 \pm 12$ & $0.0487 \pm 42$ & $0.0116 \pm 1$ & $0.078 \pm 7$ & $74 \pm 1$ \\
\hline CU180-4 & 287 & 124 & 949 & $0.137 \pm 20$ & $0.0458 \pm 86$ & $0.0119 \pm 1$ & $0.075 \pm 14$ & $76 \pm 1$ \\
\hline CU180-5 & 105 & 38 & 482 & $0.148 \pm 41$ & $0.051 \pm 17$ & $0.0116 \pm 1$ & $0.081 \pm 28$ & $74 \pm 1$ \\
\hline CU180-6 & 122 & 51 & 927 & $0.182 \pm 30$ & $0.051 \pm 13$ & $0.0117 \pm 2$ & $0.082 \pm 20$ & $75 \pm 1$ \\
\hline CU180-7 & 181 & 96 & 574 & $0.141 \pm 24$ & $0.047 \pm 10$ & $0.0117 \pm 2$ & $0.075 \pm 17$ & $75 \pm 1$ \\
\hline \multicolumn{9}{|l|}{ CU202 } \\
\hline CU202-1 & 211 & 108 & 10618 & $0.1573 \pm 47$ & $0.0576 \pm 19$ & $0.0866 \pm 6$ & $0.688 \pm 23$ & $535 \pm 3$ \\
\hline CU202-2 & 262 & 76 & 9677 & $0.124 \pm 11$ & $0.0486 \pm 46$ & $0.0111 \pm 1$ & $0.074 \pm 7$ & $71 \pm 1$ \\
\hline CU202-3 & 297 & 75 & 4944 & $0.104 \pm 14$ & $0.0497 \pm 60$ & $0.0111 \pm 1$ & $0.076 \pm 9$ & $71 \pm 1$ \\
\hline CU202-4 & 477 & 143 & 118050 & $0.0987 \pm 49$ & $0.0480 \pm 20$ & $0.0111 \pm 1$ & $0.074 \pm 3$ & $71 \pm 0.4$ \\
\hline CU202-5 & 339 & 80 & 2471 & $0.081 \pm 12$ & $0.0487 \pm 52$ & $0.0110 \pm 1$ & $0.074 \pm 8$ & $71 \pm 1$ \\
\hline CU202-6 & 351 & 114 & 1668 & $0.1044 \pm 109$ & $0.0502 \pm 47$ & $0.0111 \pm 1$ & $0.077 \pm 7$ & $71 \pm 1$ \\
\hline CU202-7 & 117 & 36 & 238 & $0.1920 \pm 449$ & $0.0553 \pm 191$ & $0.0111 \pm 3$ & $0.085 \pm 29$ & $71 \pm 2$ \\
\hline CU202-8 & 223 & 50 & 1104 & $0.0791 \pm 154$ & $0.0498 \pm 67$ & $0.0111 \pm 2$ & $0.076 \pm 10$ & $71 \pm 1$ \\
\hline
\end{tabular}

* radiogenic lead corrected using measured ${ }^{204} \mathrm{~Pb}$ 
TABLE 3

Hf isotopic compositions of zircons from the Tres Guanos granitoids, south of Iguará and Pérea

\begin{tabular}{llllrrrrr}
\hline Grain & $\begin{array}{l}\text { Spot } \\
\text { size }\end{array}$ & $\begin{array}{c}{ }^{176} \mathrm{Yb} \\
{ }^{177} \mathrm{Hf}\end{array}$ & $\frac{{ }^{176} \mathrm{Lu}}{{ }^{177} \mathrm{Hf}}$ & $\frac{{ }^{176} \mathrm{Hf}}{{ }^{177} \mathrm{Hf}}$ & Age Ma & $\frac{{ }^{176} \mathrm{Hf}}{{ }^{177} \mathrm{Hf}}(\mathrm{t})$ & $\mathrm{M}(\mathrm{t})$ & Comment \\
\hline \hline CU-202-1 & $58 \mu \mathrm{m}$ & $0.0362 \pm 10$ & $0.00111 \pm 6$ & $0.282590 \pm 18$ & $535 \pm 3.0$ & 0.282579 & $5.0 \pm 0.6$ & core \\
CU-202-2 & $58 \mu \mathrm{m}$ & $0.0233 \pm 1$ & $0.00086 \pm 0.4$ & $0.283093 \pm 12$ & $71 \pm 1.0$ & 0.283092 & $12.9 \pm 0.4$ & rim \\
CU-202-3 & $58 \mu \mathrm{m}$ & $0.0178 \pm 6$ & $0.00066 \pm 4$ & $0.283069 \pm 18$ & $71 \pm 1.0$ & 0.283068 & $12.0 \pm 0.6$ & rim \\
CU-204-2 & $40 \mu \mathrm{m}$ & $0.0272 \pm 2$ & $0.00095 \pm 1$ & $0.283074 \pm 17$ & $76 \pm 1.0$ & 0.283073 & $12.3 \pm 0.6$ & rim \\
CU-204-5 & $58 \mu \mathrm{m}$ & $0.1363 \pm 65$ & $0.00347 \pm 32$ & $0.282554 \pm 24$ & $269 \pm 1.0$ & 0.282537 & $-2.4 \pm 0.9$ & core \\
CU-204-6 & $58 \mu \mathrm{m}$ & $0.0364 \pm 8$ & $0.00135 \pm 5$ & $0.283083 \pm 25$ & $77 \pm 1.0$ & 0.283081 & $12.6 \pm 0.9$ & core \\
\hline
\end{tabular}

Analytical uncertainties quoted at 2 sigma. The error in $\varepsilon H f(t)$ combines (in quadrature) the within-run uncertainties in interference-corrected ${ }^{176} \mathrm{Hf} /{ }^{177} \mathrm{Hf}$, measured ${ }^{176} \mathrm{Lu} /{ }^{177} \mathrm{Hf}$, crystallization age and the decay constant of ${ }^{176} \mathrm{Lu}$. Uncertainties in $\mathrm{Lu} / \mathrm{Hf}$ and $\mathrm{Yb} / \mathrm{Hf}$ are large, because the zircons are zoned for trace elements.

with inherited Cambrian zircon has a lower $\varepsilon_{\mathrm{Nd}(\mathrm{t})}$ of 4.9 suggesting that the sample was derived from a mixed source comprising a depleted and an older, enriched crustal component. The strongly positive $\varepsilon_{\mathrm{Nd}(\mathrm{t})}$ value of +7.7 in sample CU204, however, does not record a large component from older crust as reflected by zircon xenocryst CU204-5. This may be explained by the presence of only a small amount of older material and/or overall younger age of the material as suggested by the young zircon xenocryst age of $270 \mathrm{Ma}$. The samples with high $\varepsilon_{\mathrm{Nd}(\mathrm{t})}$ values have $\mathrm{Nd}$ model ages of 120 to $150 \mathrm{Ma}$, suggesting that all samples contain a slightly older crustal component. Sample CU202 with a lower $\varepsilon_{\mathrm{Nd}(\mathrm{t})}$ and evidence of Ordovician material has a model age of $340 \mathrm{Ma}$, consistent with the zircon evidence.

The initial $\mathrm{Sr}$ isotopic compositions of all samples vary between 0.7031 and 0.7037 (table 4, fig. 9B). They are typical for I-type granitoids (Chappell and White, 1974) and compatible with the high initial $\varepsilon_{\mathrm{Nd}(\mathrm{t})}$ and $\varepsilon_{\mathrm{Hf}(\mathrm{t})}$ values.

DISCUSSION ON PETROGENESIS AND GEODYNAMIC IMPLICATIONS

Our zircon ages, together with published geochronological data for granitoids and ophiolite-related rocks within the northern ophiolitic mélange (NOM) of central Cuba, are summarized in figure 10. These ages place new constraints on the Late Cretaceous evolution of the NOM. The latest Cretaceous (Campanian-Maastrichtian) was a time of collision/accretion in the Caribbean region. The subduction of the Caribeana terrane began in the late Campanian and resulted in the reorganization of southwestward subduction of the proto-Caribbean lithosphere below the Caribbean plate (Pindell and others, 2005, 2006; García-Casco and others, 2008b). Arc magmatic activity in central Cuba terminated towards the end of the Campanian (ca. $70 \mathrm{Ma}$; figs. 10 and 11A; García-Casco and others, 2008b), as indicated by latest Campanian-Danian sedimentary rocks overlying the Cretaceous arc sequences (Iturralde-Vinent and others, 2008). The sedimentary piles of Caribeana, as defined by García-Casco and others $(2008 \mathrm{~b})$, were metamorphosed in a subduction zone during the latest Cretaceous to Early Paleocene (fig. 11A). García-Casco and others (2008b) suggested that subduction/accretion of Caribeana caused Tertiary flat subduction in central Cuba, during which the locus of arc magmatism may have been driven inboard towards the SW (Cayman ridge; fig. 11C) and was shut off in Cuba. This is supported by Early Danian-Early Eocene volcanic activity in the Cayman Rise/Ridge (Perfit and Heezen, 1978; Sigurdsson and others, 2000; Lewis and others, 2005). However, our new age data for granitoids from the northern ophiolite mélange suggest that arc magmatism 

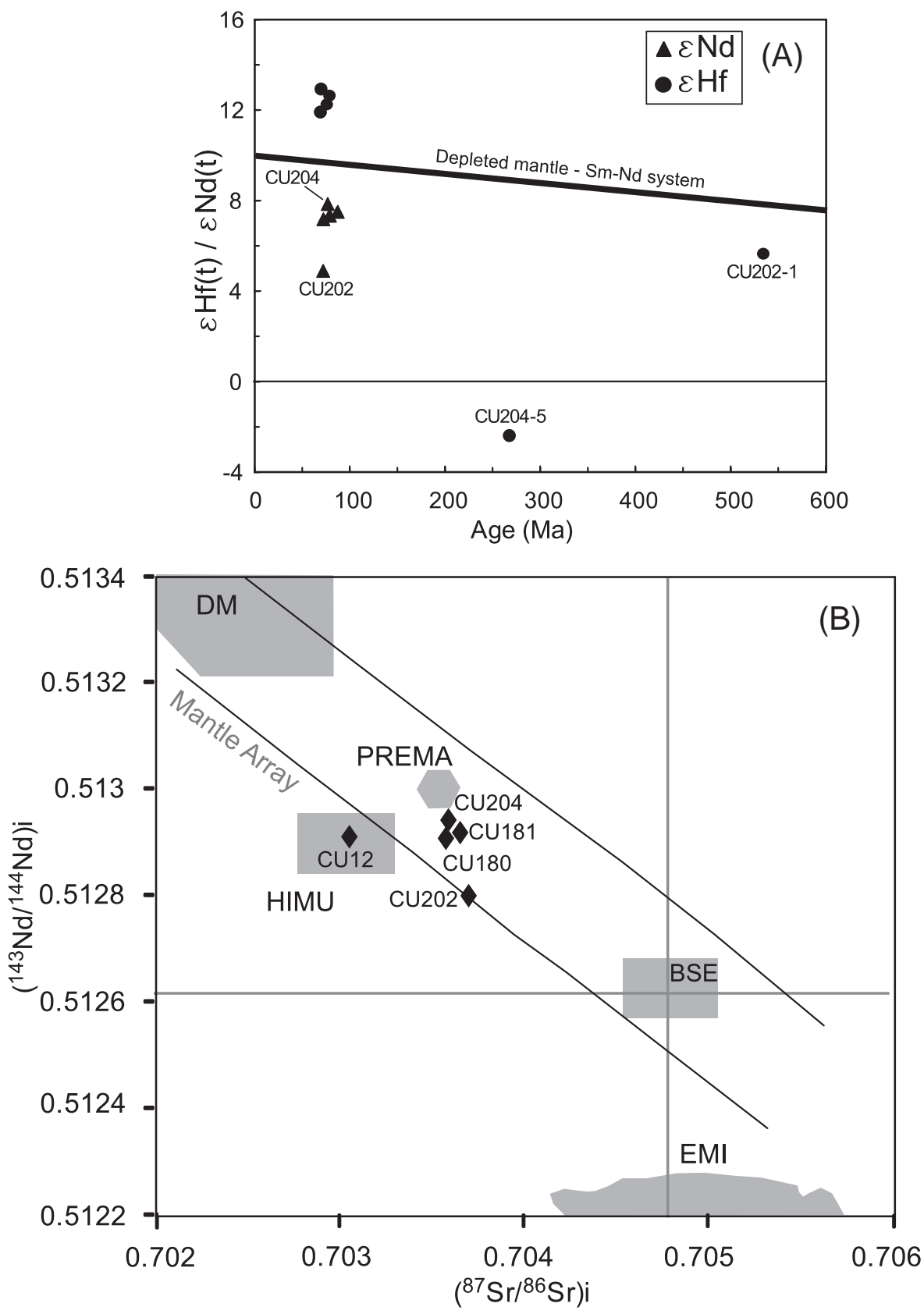

Fig. 9. (A) $\varepsilon_{\mathrm{Hf}(\mathrm{t})}$ in zircons and $\varepsilon_{\mathrm{Nd}(\mathrm{t})}$ in whole-rock samples plotted against age. A depleted mantle model curve is shown for the Sm-Nd isotopic system. $\varepsilon_{\mathrm{Hf}(\mathrm{t})}$ values for CU202-1 CU204-5 represent zircon xenocrysts. $\varepsilon_{\mathrm{Hf}(\mathrm{t})}$ values for CU202 and 204 at $c a$. 70 Ma represent magmatic values. (B) Initial ${ }^{87} \mathrm{Sr} /{ }^{86} \mathrm{Sr}$ vs. ${ }^{144} \mathrm{Nd} /{ }^{143} \mathrm{Nd}$ ratios for granitoid samples from the northern ophiolite mélange. Mantle components after Zindler and Hart (1986), Staudigel and others (1984), Hamelin and others (1986) and Wilson (1989). DM-Depleted mantle, PREMA-Prevalent mantle, HIMU-High ${ }^{238} \mathrm{U} /{ }^{204} \mathrm{~Pb}-\mathrm{mantle}$, BSE-Bulk silicate earth, EMI-Enriched mantle I, EM-2-enriched mantle 2. 


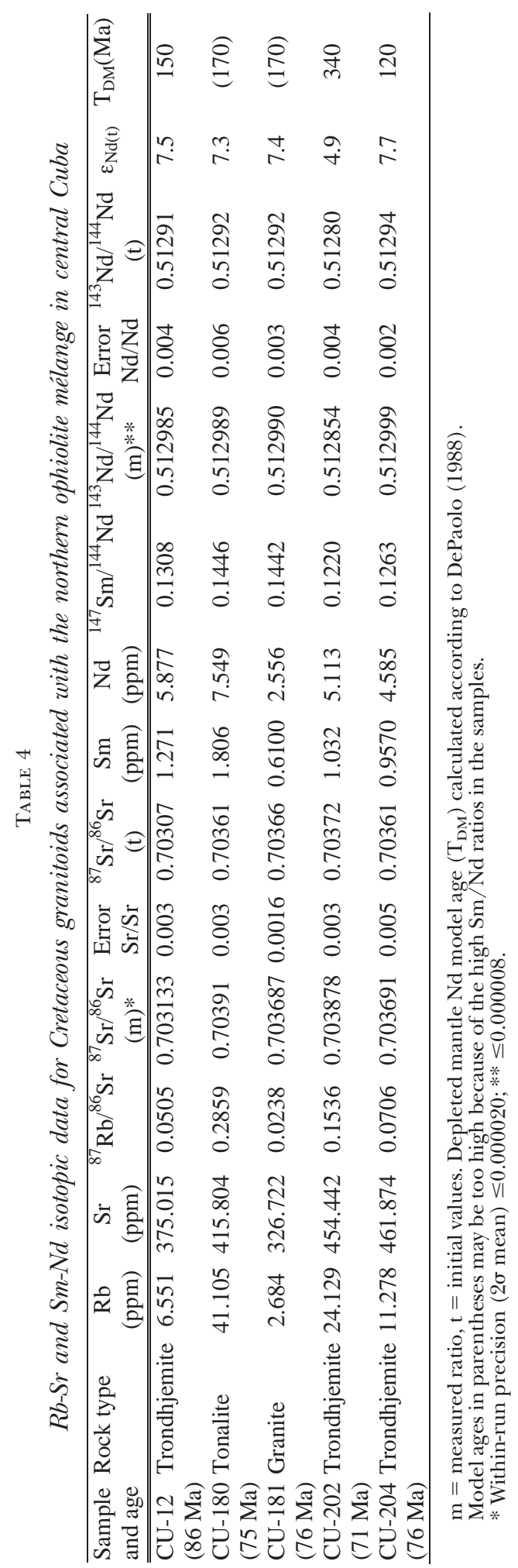




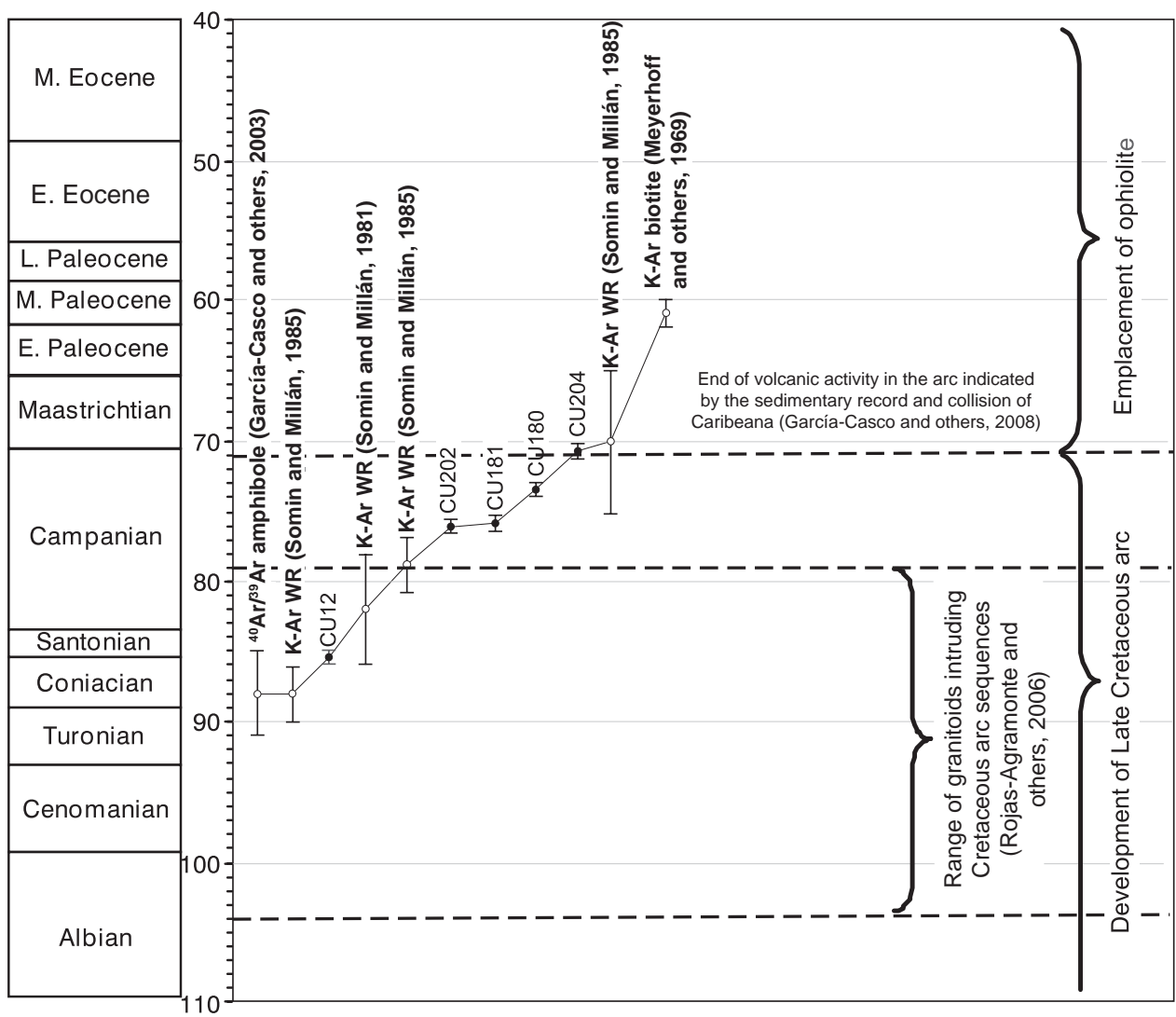

Fig. 10. Summary figure showing published ages and those of this study (bold) for granitoids and ophiolite-related rocks within the northern ophiolitic mélange of central Cuba. Errors are indicated. Geological time scale from Gradstein and others (2004). WR-whole rock.

was transferred towards the fore-arc region (that is, towards the NE) during the uppermost Cretaceous, previous to the Tertiary shift of volcanic activity towards the SW. This conclusion can be reconciled with the model of García-Casco and others (2008b) by means of slab roll-back in the Late Cretaceous and previous to arcCaribeana collision. Our data indicate that slab-roll back and associated arc magmatism in the forearc region ended by $70 \mathrm{Ma}$, reinforcing the ideas of latest Cretaceous collision/accretion of Caribeana and Tertiary flat subduction in the region.

According to Rojas-Agramonte and others (2006) the age of granitoid magmatism (batholiths intruding the Cretaceous arc sequences) in central Cuba ranges from $\sim 104$ to $81 \mathrm{Ma}$, probably indicating that the main magmatic activity in the arc ended by middle Campanian times. Trondhjemite sample CU12 falls within this age range, suggesting a broad arc/fore-arc in the region. This is consistent with Ar-Ar and K-Ar ages of metagabbros from the Iguará-Perea region (Somin and Millán, 1981; GarcíaCasco and others, 2003) that attest to mafic volcanic arc activity in the forearc between 90 and $80 \mathrm{Ma}$. The remaining samples are consistently younger ( $\sim 76$ to $71 \mathrm{Ma})$, contrary to the idea that these rocks are pre-Tithonian (Late Jurassic) in age (Hatten and others, 1958, 1988). As indicated above, these granitoids were probably generated in a pre-collision/collision calc-alkaline subduction-related environment during outboard retreat of the proto-Caribbean slab (arc magmatism would move into the 
(A) Late Campanian ( 71 Ma)
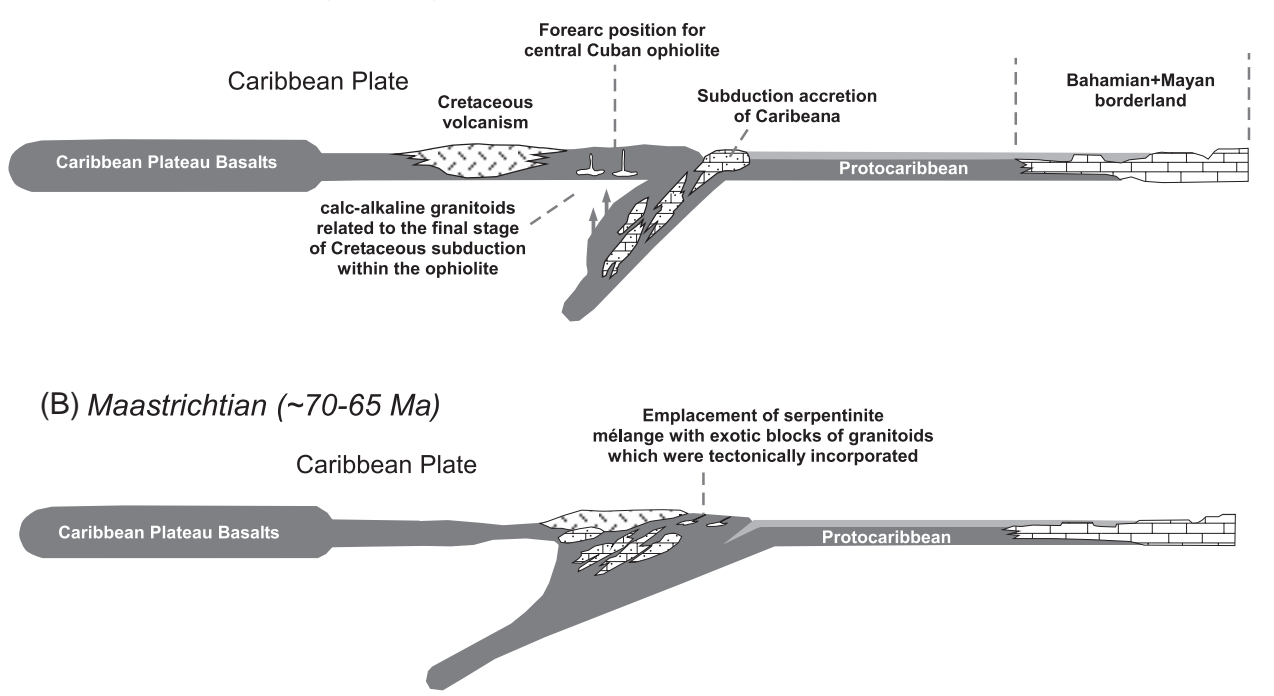

(C) Paleocene

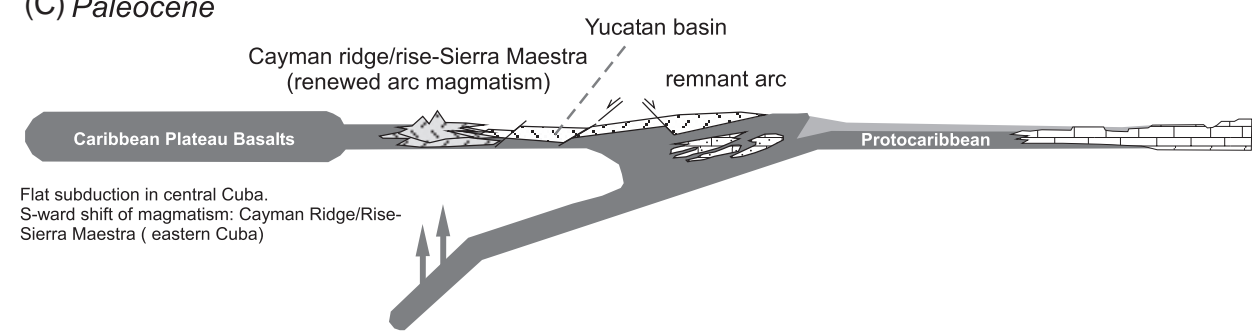

Fig. 11. Cross-section showing late Cretaceous-Paleocene evolution of the northern ophiolitic mélange in central Cuba (after García-Casco and others, 2008b). Location of Ciosi-sections shown in figure 3B.

fore-arc) just before subduction/accretion of Caribeana began. Our age data imply that tectonic emplacement of the ophiolitic mélange in central Cuba must have been later than $71 \mathrm{Ma}$ (fig. 11B) as already suggested by García-Casco and others (2008b).

The major and trace element data for granitoid rocks from the Cuban ophiolite mélange demonstrate that these rocks were generated in a supra-subduction zone (SSZ) setting. They show typical characteristics of island arc magmatism such as depletion in high field strength elements and enrichment in large ion lithophile elements relative to mid-ocean ridge basalts. Our geochemical data also suggest that the oceanic crust from which the ophiolitic mélange of central Cuba is derived was of supra-subduction type (probably located in a forearc position; fig. 11) and was related to a Late Cretaceous volcanic arc domain. Therefore, the dated blocks in the mélange represent fragments of the Caribbean and not the Proto-Caribbean plate (figs. 3B and 11) as suggested by Iturralde-Vinent (1996) and Kerr and others (1999) and are also unlikely to be derived from the roots of an Early Cretaceous remnant arc (IturraldeVinent, 1994, 1996). Mostly strongly positive initial $\varepsilon_{\mathrm{Nd}}$ and $\varepsilon_{\mathrm{Hf}}$ values, coupled with low initial ${ }^{87} \mathrm{Sr} /{ }^{86} \mathrm{Sr}$ ratios, suggest that the source of the granitoids was dominated by meta-igneous and juvenile material, whereas the contribution of continental material to the granitoid sources was subordinate. However, the radiogenic isotope data also 
indicate that assimilation of older continental crust or terrigenous sediments was of importance, and this is a new discovery that needs to be further explored. Nevertheless, the overall positive $\varepsilon_{\mathrm{Nd}(\mathrm{t})}$ and $\varepsilon_{\mathrm{Hf}(\mathrm{t})}$ values show that the granitoids originated in an intra-oceanic arc setting.

Late-stage granitoids probably interacted with the Caribeana sedimentary pile (Maya block; fig. 11), and the occurrence of rare inherited zircons in two of our peraluminous samples (CU202, CU204) may imply the involvement of subducted sediments containing an ancient zircon component. Inherited zircons can survive in relatively cool and dry peraluminous melts due to the low $\mathrm{Zr}$ saturation level in such magmas. On the other hand, the dated xenocryst zircons are not rounded but perfectly euhedral and are indistinguishable, optically and under CL, from magmatic zircons in granitoid rocks. Taking into account the ages of the inherited zircons, the most probable source region is the Maya block. The recognition of zircon inheritance in the seemingly juvenile arc/ophiolite terrane of Cuba questions the entirely intro-oceanic origin and evolution of the Caribbean plate and is of general relevance for crustal growth processes. Such inheritance has recently also been documented in other arc terranes previously considered as primitive (for example, Ali and others, 2009) and also in mid-oceanic crust far removed from any continent (Bortnikov and others, 2005; Kostitsyn and others, 2009).

CONCLUSIONS

1. The northern ophiolitic mélange (NOM) in central Cuba contains, in addition to fragments of fore-arc ophiolitic lithosphere and associated high-pressure metamorphic blocks from the subduction channel, granitoid blocks that originally formed in an island arc setting, mainly during the final stages of subduction and associated slab roll back during the Late Cretaceous, prior to collision/accretion of Caribeana in the latest Cretaceous-Early Tertiary.

2. The NOM represents fragments of the Caribbean plate and not the ProtoCaribbean lithosphere. Jurassic fauna recorded in sediments associated with the ophiolitic rocks may date the age of Caribbean (Pacific) lithosphere represented in central Cuba.

3. Inherited zircons in two peraluminous samples may imply involvement of subducted oceanic crust containing an ancient zircon component, possibly due to interaction with the Caribeana sedimentary pile (Maya block) in the latest Cretaceous. Alternatively, there may be unexposed continental crust in the deep Cuban arc terrane, questioning the entirely intra-oceanic evolution of the Caribbean plate.

\section{ACKNOWLEDGMENTS}

Y. R.-A. acknowledges a Humboldt-Foundation Georg Forster Fellowship. We thank Mr. Guangshen Ni of the Beijing SHRIMP Center for help with panning during zircon separation and Mr. Zhiqing Yang, Dr. Yuruo Shi, Mrs. Hui Zhou, Yang Chun and Qing Ye, also in the Beijing SHRIMP Center, for assistance during mount preparation, CL imaging and during calibration of the SHRIMP II instrument. We also thank Nora Groschopf and Nicole Beiser for their help in the geochemistry laboratory in Mainz as well as Linda Iacheri of Munich University for helpful discussions on $\mathrm{Sm}-\mathrm{Nd}$ and $\mathrm{Rb}-\mathrm{Sr}$ analytical methods. Last but not least we thank Fosforito from the town of Iguará in central Cuba for taking us to the Tres Guanos area in his tractor, the only way to get to that locality. We appreciate financial support from the Spanish MEC project CGL2006-08527/BTE and DFG project KR590/85-1. This is a contribution to IGCP project 546 "Subduction Zones of the Caribbean." 
APPENDix I

\author{
ANALYTICAL PROCEDURES
}

Sample Preparation

Approximately $1 \mathrm{~kg}$ of each sample was crushed to a grain size of $\sim 250 \mu \mathrm{m}$ using a jaw crusher and roller mill. A heavy mineral fraction was then produced using a Wilfley table and a Frantz magnetic separator. The final heavy mineral concentrate (mostly zircons) was obtained by panning with water and alcohol. Zircons for isotopic analysis were then handpicked during optical inspection under a binocular microscope and mounted in epoxy. About $100 \mathrm{~g}$ of sample was removed prior to preparation of the heavy mineral fraction and was pulverized in a Siebtechnik tungsten carbide mill for chemical and whole-rock isotopic analysis.

\title{
Major and Trace Element Analysis
}

Major and trace elements, including rare earth element (REE) concentrations, were determined by X-ray fluorescence spectrometry (XRF) on fused glass beads and pressed powder pellets and by laser ablation-inductively coupled plasma-mass spectrometry (LA-ICP-MS), on glass beads, respectively, at the University of Mainz. In order to obtain high-precision whole-rock data for REE and trace elements, a LA-ICP-MS technique using an automated iridium strip heater (Nehring and others, 2007) was applied. About $40 \mathrm{mg}$ of rock powder was melted on an iridium strip without flux agent. Melting of the samples to glass beads was achieved in a closed box under an argon atmosphere to suppress oxidation and to limit volatilization of elements with low boiling points (for example, $\mathrm{Cs}, \mathrm{Pb}$ ). The fused glass beads were then analyzed. Ablation was achieved with a New Wave Research UP-213 Nd:YAG laser ablation system, using a pulse repetition rate of $10 \mathrm{~Hz}$, pulse energies of $\sim 0.3 \mathrm{~mJ}$, and $100 \mu \mathrm{m}$ crater diameters. Analyses were performed on an Agilent 7500ce inductively coupled plasma-mass spectrometer in pulse counting mode (one point per peak and $10 \mathrm{~ms}$ dwell time). Data reduction was carried out using the software "Glitter." The amount of material ablated in laser sampling is different for each spot analysis. Consequently, the detection limits are different for each spot and were calculated for each individual acquisition. Detection limits generally range between 0.001 and $0.5 \mathrm{ppm}(\mu \mathrm{g} / \mathrm{g}) .{ }^{44} \mathrm{Ca}$ was used as an internal standard. Analyses were calibrated against the silicate glass reference material NIST 612 using the values of Pearce and others (1997), and the US Geological Survey (USGS) glass standard BCR-2G was measured to monitor accuracy; for more details about precision and accuracy see Nehring and others (2008). The analytical data are presented in table 1 which also lists the detection limit for each oxide or element.

\section{Whole-rock Rb-Sr and Sm-Nd Isotopic Analysis}

The analyses were carried out at the University of Granada (CIC) (Montero and Bea, 1998). Samples for $\mathrm{Sr}$ and $\mathrm{Nd}$ isotope analysis $(0.1000 \mathrm{~g})$ were digested with $\mathrm{HNO}_{3}+\mathrm{HF}$ in a Teflon-lined vessel at 200 p.s.i. The elements were separated with ion-exchange resins, and the $\mathrm{Sr}$ and $\mathrm{Nd}$ isotope ratios $\left({ }^{87} \mathrm{Sr} /{ }^{86} \mathrm{Sr}\right.$ and ${ }^{143} \mathrm{Nd} /{ }^{144} \mathrm{Nd}$ ) were determined by thermal ionization mass spectrometry (TIMS) in static mode with a Finnigan Mat 262 at the University of Granada. All reagents were ultra clean. Normalization values were ${ }^{86} \mathrm{Sr} /{ }^{88} \mathrm{Sr}=0.1194$ and ${ }^{146} \mathrm{Nd} /{ }^{144} \mathrm{Nd}=0.7219 . \mathrm{Rb}$ and $\mathrm{Sm}$ were measured by ICP-MS at the University of Granada following the procedure of Montero and Bea (1998). Blanks were 0.6 and 0.09 ng for Sr and Nd. Blanks for $\mathrm{Rb}$ and $\mathrm{Sm}$ were not measured, for elemental ratios are determined by ICP-MS. The external precision $(2 \sigma)$, estimated by analyzing 10 replicates of the standard WS-E (Govindaraju and others, 1994), was better than \pm 0.003 percent for ${ }^{87} \mathrm{Sr} /{ }^{86} \mathrm{Sr}$ and \pm 0.0015 percent for ${ }^{143} \mathrm{Nd} /{ }^{144} \mathrm{Nd}$. The ${ }^{87} \mathrm{Sr} /{ }^{86} \mathrm{Sr}$ ratio determined for the NIST $987 \mathrm{Sr}$ reference material is $0.7102500 \pm 44(2 \sigma$ external, $\mathrm{n}=106)$. Measurements of the La Jolla $\mathrm{Nd}$ international standard yielded a ${ }^{143} \mathrm{Nd} /{ }^{144} \mathrm{Nd}$ ratio of $0.5118440 \pm 67(2 \sigma$ external, $\mathrm{n}=$ 49). ${ }^{87} \mathrm{Rb} /{ }^{86} \mathrm{Sr}$ and ${ }^{147} \mathrm{Sm} /{ }^{144} \mathrm{Nd}$ were directly determined by ICP-MS at the University of Granada following the method developed by Montero and Bea (1998), with a precision better than $\pm 1.2 \%$ and \pm 0.9 percent $(2 \sigma)$ respectively.

\section{Lu-Hf Isotopes in Zircon}

The Hf isotopic data were acquired at James Cook University, Townsville, using a ThermoScientific Neptune multi-collector ICP-MS coupled to a Coherent GeoLas $193 \mathrm{~nm}$ ArF laser ablation sampling system (for details see Kemp and others, 2009). A laser repetition rate of $4 \mathrm{~Hz}$ and spot sizes of 30 to $58 \mu \mathrm{m}$ diameter were employed for the analyses. The power density at the sample was maintained at around $6 \mathrm{~J} / \mathrm{cm}^{2}$. Ablation was conducted in the standard GeoLas ablation cell containing a polycarbonate insert designed to streamline the carrier gas flow and to reduce the cell volume. The He carrier gas exiting the cell was combined with $\mathrm{Ar}$ and $\mathrm{N}_{2}$ in a small volume $\left(3 \mathrm{~cm}^{3}\right)$ glass mixing chamber prior to transport into the ICP via 
Teflon-lined plastic tubing. This ensured a smooth signal that proved easy to optimize for maximum Hf intensity. To correct for instrumental mass fractionation, the Hf isotopic data were normalized to ${ }^{179} \mathrm{Hf} /$ ${ }^{177} \mathrm{Hf}=0.7325$. Protocols for the isobaric interference correction of ${ }^{176} \mathrm{Lu}$ and ${ }^{176} \mathrm{Yb}$ on ${ }^{176} \mathrm{Hf}$ were as recommended by Woodhead and others (2004). Data were processed off-line using a customized EXCEL spreadsheet. Analysis of reference zircons Mud Tank, Temora 2 and FC1 during the session yielded values of $0.282495 \pm 3(2 \mathrm{SD}, \mathrm{n}=2), 0.282678 \pm 23(2 \mathrm{SD}, \mathrm{n}=4)$ and $0.282173 \pm 19(\mathrm{SD}, \mathrm{n}=14)$. Within-run outlier rejection was set at 3 sigma.

SHRIMP Analytical Procedure and Cathodoluminescence Imaging

Zircons were mounted in epoxy resin together with chips of the Perth Consortium standard CZ3. The mount was ground down and polished so that the zircon cores were exposed, and zircons were photographed in reflected and transmitted light and under cathodoluminescence (CL) to enable easy and best location for analytical spots during analysis. CL imaging was performed on a Hitachi SEM S-3000N equipped with a Gatan ChromaCL detector and a DigiSan II data recorder in the Beijing SHRIMP Center. Operating conditions were $9 \mathrm{kV}, 99 \mu \mathrm{A}$. The mount was then cleaned and gold-coated. Isotopic analyses were performed on the Beijing SHRIMP II sensitive high-resolution ion mass-spectrometer whose instrumental characteristics were described by De Laeter and Kennedy (1998). The analytical procedures are outlined in Compston and others (1992), Claoué-Long and others (1995), Nelson (1997) and Williams (1998). Prior to each analysis, the surface of the analysis site was pre-cleaned by rastering of the primary beam for $2-3 \mathrm{~min}$, to reduce or eliminate surface common $\mathrm{Pb}$. Precise dating of young zircons by SIMS is best achieved by using ${ }^{206} \mathrm{~Pb} /{ }^{238} \mathrm{U}$ ages (see Black and others, 2003 and Black and Jagodzinski, 2003 for explanation), and the reduced ${ }^{206} \mathrm{~Pb} /{ }^{238} \mathrm{U}$ ratios and $\mathrm{U}$ contents were normalized to $\mathrm{CZ3}\left({ }^{206} \mathrm{~Pb} /{ }^{238} \mathrm{U}=0.09432\right.$, adopted age: $=$ $564 \mathrm{Ma}, \mathrm{U}=550 \mathrm{ppm}) . \mathrm{Pb} / \mathrm{U}$ ratios in the unknown samples were corrected using the $\ln (\mathrm{Pb} / \mathrm{U}) /$ $\ln (\mathrm{UO} / \mathrm{U})$ relationship as measured in standard CZ3 and as outlined in Compston and others (1984) and Nelson (1997). The $1 \sigma$ error in the ratio ${ }^{206} \mathrm{~Pb} /{ }^{238} \mathrm{U}$ during analysis of all standard zircons during this study was between 1.03 and 1.43 percent. Primary beam intensity was between 4 and $4.5 \mathrm{nA}$, and a Köhler aperture of $100 \mu \mathrm{m}$ diameter was used, giving a slightly elliptical spot size of about $30 \mu \mathrm{m}$. Peak mass resolution was about 5000 , enabling clear separation of the ${ }^{208} \mathrm{~Pb}$-peak from the $\mathrm{HfO}$ peak. Sensitivity was about $30 \mathrm{cps} / \mathrm{ppm} \mathrm{Pb}$ per nA. Analyses of samples and standards were alternated to allow assessment of $\mathrm{Pb}^{+} / \mathrm{U}^{+}$discrimination.

Raw data reduction and error assessment followed the method described by Nelson (1997). Common Pb corrections were applied using the ${ }^{204} \mathrm{~Pb}$-correction method and assuming the isotopic composition of Broken Hill Lead as common $\mathrm{Pb}$ is thought to be surface-related (Kinny, 1986). The analytical data are presented in table 2. Errors for individual analyses are based on counting statistics and are at the $1 \sigma$ level and include the uncertainty of the standard added in quadrature. Errors for pooled analyses are at $2 \sigma$ or 95 percent confidence.

\section{REFERENCES}

Ali, K. A., Stern, R. J., Manton, W. I., Kimura, J.-I., and Kamees, H. A., 2009, Geochemistry, Nd isotopes and U-Pb SHRIMP zircon dating of Neoproterozoic volcanic rocks from the Central Eastern Desert of Egypt: New insights into the $\sim 750 \mathrm{Ma}$ crust-forming event: Precambrian Research, v. 171, n. 1-4, p. 1-22, doi:10.1016/j.precamres.2009.03.002.

Andó, J., Harangi, Sz., Szakmány, By., and Dosztály, L., 1996, Petrología de la asociación ofiolítica de Holguín, in Iturralde-Vinent, M. A., editor, Ofiolitas y Arcos Volcánicos de Cuba: Miami, USA, IGCP Project 364 Special Contribution 1, p. 154-176.

Barker, F., 1979, Trondhjemite: definition, environment and hypothesis oforigin, in Barker, F., editor, Trondhjemltes, dacites and related rocks: Amsterdam, Elsevier Scientific Publishing Company, Developments in Petrology, v. 6, p. 1-12.

Black, L. P., and Jagodzinski, E. A., 2003, Importance of establishing sources of uncertainty for the derivation of reliable SHRIMP ages: Australian Journal of Earth Sciences, v. 50, n. 4, p. 503-512, doi:10.1046/j.14400952.2003.01007.x.

Black, L. P., Kamo, S. L., Allen, C. M., Aleinikoff, J. N., Davis, D. W., Korsch, R. J., and Foudoulis, C., 2003, TEMORA 1: a new zircon standard for Phanerozoic U-Pb geochronology: Chemical Geology, v. 200, n. 1-2, p. 155-170, doi:10.1016/S0009-2541(03)00165-7.

Blanco-Quintero, I., García-Casco, A., Rojas-Agramonte, Y., Rodriguez Vega, A., Lázaro, C., and ItrurraldeVinent, M. A., 2010, Metamorphic evolution of subducted hot oceanic crust, La Corea mélange, Cuba: American Journal of Science, v. 310, p. 889-915, doi:10.2475/11.2010.01.

Blein, O., Guillot, S., Lapierre, H., Mercier de Lépinay, B., Lardeaux, J.-M., Millán Trujillo, G., Campos, M., and Garcia, A., 2003, Geochemistry of the Mabujina Complex, Central Cuba: Implications on the Cuban Cretaceous arc rocks: Journal of Geology, v. 111, p. 89-101, doi:10.1086/344666.

Bloomer, S. H., B. Taylor, MacLeod, C. J., Stern, R. J., Fryer, P, Hawkins, J. W., and Johnson, L., 1995, Early Arc volcanism and the Ophiolite problem: A perspective from drilling in the Western Pacific, in Taylor, B., and Natland, J., editors, Active Margins and Marginal Basins of the Western Pacific: American Geophysical Union Monograph Series, v. 88, p. 67-96. 
Bortnikov, N. S., Savel'eva, G. N., Matukov, D. I., Sergeev, S. A., Berezhnaya, N. G., Lepekhina, E. N., and Antonov, A. V., 2005. The zircon age of plagiogranites and gabbros based on SHRIMP data: Pleistocene intrusion in the MAR rift valley, $5^{\circ} 30.6^{\prime}-5^{\circ} 32.4^{\prime} \mathrm{N}$ : Doklady Earth Sciences, v. 404, p. 1054-1058.

Brown, M., and D'Lemos, R. S., 1991, The cadomian granites of Mancellia, northeast Armorican Massif of France: relationship to the St. Malo migmatite belt, petrogenesis and tectonic setting: Precambrian Research, v. 51, n. 1-4, p. 393-427, doi:10.1016/0301-9268(91)90110-V.

Chappell, B. W., and White, A. J. R., 1974, Two contrasting granite types: Pacific Geology, v. 8, p. 173-174.

Claoué-Long, J. C., Compston, W., Roberts, J., and Fanning, C. M., 1995, Two Carboniferous ages: a comparison of SHRIMP zircon dating with conventional zircon ages and ${ }^{40} \mathrm{Ar} /{ }^{39} \mathrm{Ar}$ analyses in Breggen, W. A., Kent, D. V., Aubry, M.-P., and Hardenbol, J., editors, Geochronology, Time Scales, and Stratigraphic Correlation: Society of Sedimentary Geology, Special Publication, v. 54, p. 3-21.

Coleman, R. G., and Donato, M. M., 1979, Oceanic plagiogranite revised, in Barker, F., editor, Trondhjemites, dacites and related rock: Elsevier Scientific Publishing Company, New York, p. 149-168.

Coleman, R. G., and Peterman, Z. E., 1975, Oceanic plagiogranites: Journal of Geophysical Research, v. 80, n. 8, p. 1099-1108, doi:10.1029/JB080i008p01099.

Compston, W., Williams, I. S., and Myer, C., 1984, U-Pb geochronology of zircons from Lunar Breccia 73217 using a sensitive high mass-resolution ion-microprobe: Journal of Geophysical Research, v. 89, n. S2, p. B525-B534, doi:10.1029/JB089iS02p0B525.

Corfu, F., Hanchar, J. M., Hoskin, P. W. O., and Kinny, P, 2003, Atlas of zircon textures, in Hanchar, J. M., and Hoskin, P. W. O., editors, Zircon: Reviews in Mineralogy and Geochemistry, v. 53, p. 469-500, doi: $10.2113 / 0530469$.

Cvetković, V., Šarić, K., Knežević, V., Gajić, V., Karamata, S., and Popević, A., 2004, Allochthonous Variscan granitoids of Mt. Zlatibor-a specific feature of the Dinaride ophiolite melange: Florence, Italy, August 20-28.2004a, 32nd International Geological Congress, p. 1101-1102, Abstracts.

De Laeter, J. R., and Kennedy, A. K., 1998, A double focusing mass spectrometer for geochronology: International Journal of Mass Spectrometry, v. 178, n. 1-2, p. 43-50, doi:10.1016/S1387-3806(98) 14092-7.

DePaolo, D. J., 1988, Age dependence of the composition of continental crust: evidence from Nd isotopic variations in granitic rocks: Earth and Planetary Science Letters, v. 90, p. 263-271, doi:10.1016/0012821X (88)90130-6.

Díaz de Villalvilla, L., 1997. Caracterización geológica de las formaciones volcánicas y volcano-sedimentarias en Cuba Central: Provincias Cienfuegos, Villa Clara, Sancti Spiritus, in Furrazola-Bermúdez, G., Núñez Cambra, K., editors, Estudios sobre Geología de Cuba. La Habana: Centro Nacional de Información Geológica, p. 325-344.

Eguipko, O., Sukar, K., Pavlov, V., Pérez, M., Gurbanov, A., and Soto, T., 1984, Las principales particularidades petroquímicas y los tipos de formaciones de los granitoides del eugeosinclinal cubano: Revista Ciencias de la Tierra y del Espacio, v. 9, p. 57-73.

García-Casco, A., Torres Roldán, R. L., Millán Trujillo, G., Monié, P., and Haissen, F., 2001, High-grade metamorphism and hydrous melting of metapelites in the Pinos Terrane (W. Cuba): Evidence for crustal thickening and extension in the northern Caribbean collisional belt: Journal of Metamorphic Geology, v. 19, n. 6, p. 699-715, doi:10.1046/j.0263-4929.2001.00343.x.

García-Casco, A., Torres-Roldán, R. L., Millán, G., Monié, P., and Schneider, J. 2002, Oscillatory zoning in eclogitic garnet and amphibole, Northern Serpentinite Melange, Cuba: a record of tectonic instability during subduction?: Journal of Metamorphic Geology, v. 20, n. 6, p. 581-598, doi:10.1046/j.15251314.2002.00390.x.

García-Casco, A., Pérez de Arce, C., Millán, G., Iturralde-Vinent, M., Fonseca, E., Torres-Roldán, R., Nuñez, K., and Morata, D., 2003, Metabasites from the northern serpentinite belt (Cuba) and a metamorphic perspective of plate tectonic models for the Caribbean region: Memorias Geomin 2003, La Habana, p. 24-28, ISBN 959-7117-11-8.

García-Casco, A., Torres-Roldán, R. L., Iturralde-Vinent, M. A., Millán, G., Núñez Cambra, K., Lázaro, C., and Rodríguez Vega, A., 2006, High pressure metamorphism of ophiolites in Cuba, in Iturralde-Vinent, M., and Lidiak, E. G., editors, Caribbean Plate Tectonics: Stratigraphic, magmatic, metamorphic and tectonics events (UNESCO/IUGS IGCP Project 433): Geologica Acta, v. 4, n. 1-2, p. 63-88, doi:10.1344/105.000000358.

García-Casco, A., Lázaro, C., Rojas-Agramonte, Y., Kröner, A., Torres-Roldán, R. L., Núñez, K., Neubaurer, F., Millán, G., and Blanco-Quintero, I., 2008a, Partial melting and counterclockwise P-T path of subducted oceanic crust (Sierra del Convento Mélange, Cuba): Journal of Petrology, v. 49, n. 1, p. 129-161, doi:10.1093/petrology/egm074.

García-Casco, A., Iturralde-Vinent, M. A., Pindell, J., 2008b, Latest Cretaceous Collision/Accretion between the Caribbean Plate and Caribeana: Origin of Metamorphic Terranes in the Greater Antilles: International Geology Review, v. 50, p. 781-809, doi:10.2747/0020-6814.50.9.781.

García-Delgado, D. E., Delgado Damas, R., Millán Trujillo, G., Díaz de Villalvilla, L., Sukar Sastroputro, K., Llanes, I., Bernal, L., Rojas, Y., Pérez Pérez, C., Díaz Otero, C., Furrazola Bermúdez, G., Peñalver, L., García Cádiz, I., Pardo, M., Suárez, V., and Duani, E., 1998, Mapa Geológico de Cuba Central (Provincias Cienfuegos, Villa Clara y Sancti Spiritus): Memorias del III Congreso Cubano de Geología, I:263-266, a escala 1:100 000 .

Gervilla, F., Proenza, J. A., Frei, R., González-Jiménez, J. M., Garrido, C. J., Melgarejo, J. C., Meibom, A., Díaz-Martínez, R., and Lavaout, W., 2005, Distribution of platinum-group elements and Os isotopes in chromite ores from Mayarí-Baracoa ophiolitic belt (eastern Cuba): Contributions to Mineralogy and Petrology, v. 150, p. 589-607, doi:10.1007/s00410-005-0039-2.

Govindaraju, K., Potts, P. J., Webb, P. C., and Watson, J. S., 1994, 1994 Report on Whin Sill dolerite WS-E from England and Pitscurrie microgabbro PM-S from Scotland: Assessment by one hundred and four international laboratories: Geostandards Newsletter, v. 18, p. 211-300, doi:10.1111/j.1751908X.1994.tb00520.x. 
Gradstein, F., Ogg, J., and Smith A., editors, 2004, A geologic time scale 2004: Cambridge, Cambridge University Press, $589 \mathrm{p}$.

Hall, C. M., Kesler, S. E., Russel, N., Piñero, E., Sánchez, R., Pérez, M., Moreira, J., and Borges, M., 2004, Age and tectonic setting of the Camagüey volcanic-intrusive arc, Cuba: Late Cretaceous extension and uplift in the western Greater Antilles: Journal of Geology, v. 11, p. 521-542, doi:10.1086/422664.

Hamelin, B., Dupré, B., and Allègre, C. J., 1986, Pb-Sr-Nd isotopic data of Indian Ocean ridges: new evidence of large-scale mapping of mantle heterogeneities: Earth and Planetary Science Letters, v. 76, p. 288-298, doi:10.1016/0012-821X(86)90080-4.

Hatten, C. W., Schooler, O. E., Giedt, N. R., and Meyerhoff, A. A., 1958, Geology of central Cuba, Eastern Las Villas and Western Camagüey provinces, Cuba: Oficina Nacional de Recursos Minerales, MINBAS, La Habana (Inédito), $250 \mathrm{p}$.

Hatten, C. W., Somin, M. L., Millán, G., Renne, P., Kistler, R. W., and Mattison, J. M., 1988, Tectonostratigraphic units of central Cuba: Barbados, Proceedings of the 11th Caribbean Geological Conference, p. $1-13$.

Irvine, T. N., and Baragar, W. R. A., 1971, A guide to the chemical classification of the common volcanic rocks: Canadian Journal of Earth Sciences, v. 8, p. 523-548, doi:10.1139/e71-055.

Iturralde-Vinent, M. A., 1989, Role of ophiolites in the geological constitution of Cuba: Geotectonics, v. 4, p. 63-74.

1994, Cuban geology: A new plate tectonic synthesis: Journal of Petroleum Geology, v. 17, n. 1, p. 39-70, doi:10.1111/j.1747-5457.1994.tb00113.x.

_ 1996, Introduction to Cuban geology and geophysics, in Iturralde-Vinent, M. A., editor, Cuban ophiolites and volcanic arcs: Miami, International Geological Correlation Program, Project. 364, p. 3-35.

1998, Synopsis de la constitución geológica de Cuba: Acta Geologica Hispanica, v. 33, n. 1-4, p. 9-56. 2006, Meso-Cenozoic Caribbean paleogeography: Implications for the historical biogeography of the region: International Geology Review, v. 48, p. 791-827, doi:10.2747/0020-6814.48.9.791.

Iturralde-Vinent, M. A., Díaz Otero, C., García-Casco, A., and van Hinsbergen, D. J. J., 2008, Palaeogene Foredeep Basin Deposits of North-Central Cuba: A Record of Arc-Continent Collision between the Caribbean and North American Plates: International Geology Review, v. 50, n. 10, p. 863-884, doi: $10.2747 / 0020-6814.50 .10 .863$.

Kamei, A., 2004, An adakitic pluton on Kyushu Island, southwest Japan arc: Journal of Asian Earth Sciences, v. 24, n. 1, p. 43-58, doi:10.1016/j.jseaes.2003.07.001.

Karsli, O., Chen, B., Aydin, F., Şen, C., 2007, Geochemical and Sr-Nd-Pb isotopic compositions of the Eocene Dolek and Saricicek Plutons, Eastern Turkey: Implications for magma interaction in the genesis of high-K calc-alkaline granitoids in a post-collision extensional setting: Lithos, v. 98, n. 1-4, p. 67-96, doi:10.1016/j.lithos.2007.03.005.

Kemp, A. I. S., Foster, G. L., Schersten, A., Whitehouse, M. J., Darling, J., and Storey, C., 2009, Concurrent $\mathrm{Pb}-\mathrm{Hf}$ isotope analysis of zircon by laser ablation multi-collector ICP-MS, with implications for the crustal evolution of Greenland and the Himalaya: Chemical Geology, v. 261 (3-4), p. 244-260, doi:10.1016/j.chemgeo.2008.06.019.

Kerr, A. C., Iturralde-Vinent, M. A., Saunders, A. D., Babbs, T. L., and Tarney, J., 1999, A new plate tectonic model of the Caribbean: Implications from a geochemical reconnaissance of Cuban Mesozoic volcanic rocks: Geological Society of America Bulletin, v. 111, n. 11, p. 1581-1599, doi:10.1130/0016-

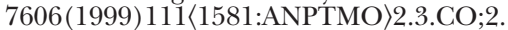

Kinny, P. D., 1986, 3820 Ma zircons from a tonalitic Amîtsoq gneiss in the Godthåb district of southern West Greenland: Earth and Planetary Science Letters, v. 79, n. 3-4, p. 337-347, doi:10.1016/0012$821 X(86) 90190-1$.

Kostitsyn, Yu. A., Belousova, E. A., Bortnikov, N. S., and Sharkov, E. V., 2009, Zircons in gabbroid formations from the axial zone of the mid-Atlantic ridge: $\mathrm{U}-\mathrm{Pb}$ age and ${ }^{176} \mathrm{Hf} /{ }^{177} \mathrm{Hf}$ ratio (Results of investigations by the laser ablation method): Doklady Earth Sciences, v. 429, n. 1, p. 1305-1309, doi:10.1134/ S1028334X09080145.

Lázaro, C., and García-Casco, A., 2008, Geochemical and Sr-Nd isotope signatures of pristine slab melts and their residues (Sierra del Convento mélange, eastern Cuba): Chemical Geology, v. 255, n. 1-2, p. $120-$ 133, doi:10.1016/j.chemgeo.2008.06.017

Lázaro, C., García-Casco, A., Rojas-Agramonte, Y., Kröner, A., Neubauer, F., and Iturralde-Vinent, M., 2009, Fifty-five-million-year history of oceanic subduction and exhumation in the northern edge of the Caribbean plate (Sierra del Convento mélange, Cuba): Journal of Metamorphic Geology, v. 27 (1), p. 19-40, doi:10.1111/j.1525-1314.2008.00800.x.

Lewis, J. F., Perfit, M. R., Mattietti, G., Aravalo, R., Mortensen, J., Ullrich, T., Friedman, R., and Kamenov, G. D., 2005, Anomalous granitoid compositions from the northwestern Cayman Trench: Implications for the composition and evolution of the Cayman ridge: San Juan de Puerto Rico, Transactions of the 17 th Caribbean Conference, p. 49-50.

Li, W.-X., and Li, X.-H., 2003, Adakitic granites within the NE Jiangxi ophiolites, South China: geochemical and Nd isotopic evidence: Precambrian Research, v. 122, n. 1-4, p. 29-44, doi:10.1016/S03019268(02)00206-1.

Llanes, A. L., García, D. E., and Meyerhoff, D. H., 1998, Hallazgo de fauna jurásica (Tithoniano) en ofiolitas de Cuba central: La Habana, III Congreso Cubano de Geología y Minería 2, Sociedad Cubana de Geología, Memorias, p. 241-244.

Marchesi, C., Garrido, C. J., Godard, M., Proenza, J. A., Gervilla, F., and Blanco-Moreno, J., 2006, Petrogenesis of highly depleted peridotites and gabbroic rocks from the Mayarí-Baracoa Ophiolitic Belt (eastern Cuba): Contributions to Mineralogy and Petrology, v. 151, n. 6, p. 717-736, doi:10.1007/s00410006-0089-0. 
McDougall, I., and Harrison, T. M., 1999, Geochronology and thermochronology by the ${ }^{40} \mathrm{Ar} /{ }^{39} \mathrm{Ar}$ method, $2^{\text {nd }}$ edition: New York, Oxford University Press, Inc, 269 p.

Metcalf, R. V., and Shervais, J. W., 2008, Suprasubduction-zone ophiolites: Is there really an ophiolite conundrum?, in Wright, J. E., and Shervais, J. W., editors, Ophiolites, arc, and batholiths: A tribute to Cliff Hopson: Geological Society of America, Special Paper, v. 438, p. 191-222, doi:10.1130/ 2008.2438(07).

Meyerhoff, A. A., Khudoley, K. M., and Hatten, C. W., 1969, Geologic significance of radiometric dates from Cuba: American Association of Petroleum Geologists Bulletin, v. 53, n. 12, p. 2494-2500.

Millán, G., 1996, Metamorfitas de la asociación ofiolítica de Cuba, in Iturralde-Vinent, M., editor, Cuban ophiolites and volcanic arcs: Miami, Florida, Special Contribution no. 1 to IGCP Project 364, p. 131-146.

Millán, G., and Somin, M. L., 1985, Condiciones geológicas de la constitución de la capa granitometamorfica de la corteza terrestre de Cuba: Ciudad Habana, Instituto de Geología y Paleontología, $83 \mathrm{p}$.

Miyashiro, A., 1973, The Troodos ophiolitic complex was probably formed in an island arc: Earth and Planetary Science Letters, v. 19, n. 2, p. 218-224, doi:10.1016/0012-821X(73)90118-0.

Montero, P., and Bea, F., 1998, Accurate determination of ${ }^{87} \mathrm{Rb} /{ }^{86} \mathrm{Sr}$ and ${ }^{147} \mathrm{Sm} /{ }^{144} \mathrm{Nd}$ ratios by inductively coupled plasma mass spectrometry in isotope geoscience: an alternative to isotope dilution analyses: Analytica Chimica Acta, v. 358, n. 3, p. 227-233, doi:10.1016/S0003-2670(97)00599-0.

Nance, R. D., Miller, B. V., Keppie, J. D., Murphy, J. B., and Dostal, J., 2007, Vestige of the Rheic Ocean in North America: The Acatlán Complex of southern México, in Linnemann, U., Nance, R. D., Kraft, P., and Zulaf, G., editors, The Evolution of the Rheic Ocean: From Avalonian-Cadomian active margin to Alleghenian-Variscan collision: Geological Society of America Special Paper, v. 423, p. 437-452, doi: $10.1130 / 2007.2423(21)$

Nehring, F., Jacob, D. E., Barth, M. G., and Foley, S. F., 2008, Laser-ablation ICP-MS analysis of siliceous rock glasses fused on an iridium strip heater using $\mathrm{MgO}$ dilution: Microchimica Acta, v. 160, n. 1-2, p. 153-163, doi:10.1007/s00604-007-0819-7.

Nelson, D. R., 1997, Compilation of SHRIMP U-Pb zircon geochronology data, 1996: Geological Survey of Western Australia, Record 1997/2, 189 p.

Palmer, A. R., 1983, The decade of North American geology 1983 geologic time scale: Geology, v. 11, n. 9, p. 503-504, doi:10.1130/0091-7613(1983)11<503:TDONAG〉2.0.CO;2.

Pearce, J. A., Harris, N. B. W., and Tindle, A. G., 1984, Trace element discrimination diagrams for the tectonic interpretation of granitic rocks: Journal of Petrology, v. 25, p. 956-983, doi:10.1093/petrology/ 25.4.956.

Pearce, N. J. G., Perkins, W. T., Westgate, J. A., Gorton, M. P., Jackson, S. E., Neal, C. R., and Chenery, S. P., 1997, A compilation of new and published major and trace element data for NIST SRM 610 and NIST SRM 612 glass reference materials: Geostandards Newsletter, v. 21, n. 1, p. 115-144, doi:10.1111/j.1751908X.1997.tb00538.x.

Perfit, M. R., and Heezen, B. C., 1978, The geology and evolution of the Cayman Trench: Geological Society of America Bulletin, v. 89, n. 8, p. 1155-1174, doi:10.1130/0016-7606(1978)89〈1155:TGAEOT〉2.0.CO;2.

Pindell, J., and Kennan L., 2009, Tectonic evolution of the Gulf of Mexico, Caribbean and northern South America in the mantle reference frame: an update, in James, K., Lorente, M. A., and Pindell, J., editors, The Origin and Evolution of the Caribbean Plate: Geological Society, London, Special Publications, v. 328, p. 1-55, doi:10.1144/SP328.1.

Pindell, J., Kennan, L., Maresch, W. V., Stanek, K.-P., Draper, G., and Higgs, R., 2005, Plate-kinematics and crustal dynamics of circum-Caribbean arc-continent interactions and tectonic controls on basin development in Proto-Caribbean margins, in Avé Lallemant, H. G., and Sissons, V. B., editors, Proto-Caribbean margins, in Caribbean-South American plate interactions, Venezuela: Geological Society of America Special Paper, v. 394, p. 7-52, doi:10.1130/0-8137-2394-9.7.

Pindell, J., Kennan, L., Stanek, K. P., Maresch, W. V., and Draper, G., 2006, Foundations of Gulf of Mexico and Caribbean evolution: eight controversies resolved, in Itturalde-Vinent, M. A., and Lidiak, E. G., editors, Caribbean Plate Tectonics: Stratigraphic, magmatic, metamorphic and tectonics events (UNESCO/IUGS IGCP Project 433): Geologica Acta, v. 4, p. 303-341, doi:10.1344/105.000000371.

Proenza, J., Gervilla, F., Melgarejo, J. C., and Bodinier, J.-L., 1999, Al- and Cr-rich chromitites from the Mayarí-Baracoa ophiolitic belt (eastern Cuba): consequence of interaction between volatile-rich melts and peridotites in suprasubduction mantle: Economic Geology, v. 94, n. 4, p. 547-566, doi:10.2113/ gsecongeo.94.4.547.

Proenza, J. A., Melgarejo, J. C., Gervilla, F., Rodríguez-Vega, A., Díaz-Martínez, R., Ruiz-Sánchez, R., and Lavaut, W., 2003, Coexistence of Cr- and Al-rich ophiolitic chromitites in a small area: the Sagua de Tánamo district, Eastern Cuba, in Eliopoulos, D. G., and others, editors, Mineral Exploration and Sustainable Development: Proceedings Of The Seventh Biennial SGA Meeting On Mineral Exploration And Sustainable Development, Athens, Greece, August 24-28, 2003: Rotterdam Netherlands, Millpress, p. 631-634.

Pushcharovsky, Yu., editor, 1988. Mapa geológico de la Républica de Cuba: Academy of Sciences of Cuba and USSR, escala 1:250 000 (40 sheets).

Renne, P. R., Mattinson, J. M., Hatten, C. W., Somin, M., Onstott, T. C., Millán, G., and Linares, E., 1989, ${ }^{40} \mathrm{Ar} /{ }^{39} \mathrm{Ar}$ and $\mathrm{U} / \mathrm{Pb}$ evidence for Late Proterozoic (Grenville age) continental crust in north-central Cuba and regional tectonic implications: Precambrian Research, v. 42, n. 3-4, p. 325-341, doi:10.1016/ 0301-9268(89)90017-X.

Rojas-Agramonte, Y., Kröner, A., García-Casco, A., Iturralde-Vinent, M. A., Wingate, M. T. D., and Liu, D. Y., 2006, Review of zircon ages from Cuba and their geodynamic interpretations: Geophysical Research Abstracts, v. 8, p. 04943. SRef-ID: 1607-7962/gra/EGU06-A-04943. 
Šarić, K., Cvetković, V., Romer, R. L. Christofides, G., and Koroneos, A., 2009, Granitoids associated with East Vardar ophiolites (Serbia, F.Y.R. of Macedonia and northern Greece): Origin, evolution and geodynamic significance inferred from major and trace element data and Sr-Nd-Pb isotopes: Lithos, v. 108 n. 1-4, p. 131-150, doi:10.1016/j.lithos.2008.06.001

Schneider, J., 2000, Origines et chemins P, T, $t$ d'éclogites de Cuba (Cara) exhumes en contexte de subduction: University of Montpellier II, France, Unpublished DEA report.

Shand, S. J., 1943, Eruptive rocks: Their genesis, composition, classification, and their relation to oredeposits with a chapter on meteorite, $2^{\text {nd }}$ edition: New York, John Wiley and Sons, p. 1-144.

Shervais, J. W., 2001, Birth, death, and resurrection: The life cycle of suprasubduction zone ophiolites: Geochemistry, Geophysics, Geosystems, v. 2, n. 1, 1010, 45 p., doi:10.1029/2000GC000080.

Sigurdsson, H., Kelley, S., Leckie, R. M., Carey, S., Bralower, T., and King, J., 2000, History of circumCaribbean explosive volcanism: ${ }^{40} \mathrm{Ar} /{ }^{39} \mathrm{Ar}$ dating of tephra layer, in Leckie, R. M., Sigurdsson, H., Acton, G. D., and Draper, G., editors: College Station, Texas, Proceedings of the Ocean Drilling Program, Scientific Results, v. 165, p. 299-314, doi:10.2973/odp.proc.sr.165.021.2000.

Somin, M., and Millán, G., 1981, Geology of the metamorphic complexes of Cuba: Moscow, Moscow, 218 p. (in Russian).

Staudigel, H., Zindler, A., Hart, S. R., Leslie, T., Chen, C.-Y., and Clague, D., 1984, The isotope systematics of a juvenile intraplate volcano: $\mathrm{Pb}, \mathrm{Nd}$, and $\mathrm{Sr}$ isotope ratios of basalts from Loihi Seamount, Hawaii: Earth and Planetary Science Letters, v. 69, n. 1, p. 13-29, doi:10.1016/0012-821X(84)90071-2.

Stern, R. J., 2004, Subduction initiation: spontaneous and induced: Earth and Planetary Science Letters, v. 226, n. 3-4, p. 275-292, doi:10.1016/j.epsl.2004.08.00.

Sukar, K., and Pérez, M., 1988, Rubidio, estroncio y potasio como indicadores petrológicos de los granitoides de Cuba central: Serie Geologica, MINBAS, v. 3, p. 55-66.

Sukar, K., Pérez, M., and Lidiak, E. G., 1998, Petrogénesis de los granitoides del arco volcánico cretácico de Cuba Central (región de Las Villas): Havana, Abstracts, 3rd Cuban Congres of Geology and Minerals, v. 2 , p. $255-257$.

Sukar, K., Pérez, M., Llanes, A. I., Ulloa, M., and Rodríguez, R., 2002, Oceanic plagiogranites of Cuba: Barbados, June 16-23, 2002, 16th Caribbean Geological Conference, Report of the IGCP Project 433 Caribbean Plate Tectonics Field Workshop and Business Meeting.

Sun, S.-s., and McDonough, W. F., 1989, Chemical and Isotopic Systematics of oceanic basalts: implications for Mantle Composition and Processes, in Saunders, A. D., and Norry, M. J., editors, Magmatism in the Ocean Basins: Geological Society, London, Special Publications, v. 42, p. 313-345, doi:10.1144/ GSL.SP.1989.042.01.19.

Torres, R., Ruíz, J., Patchett, P. J., and Grajales, J. M., 1999, Permo-Triassic continental arc in eastern Mexico; Tectonic implications for reconstructions of southern North America, in Bartolini, C., Wilson, J. L., and Lawton, T. F., editors, Mesozoic Sedimentary and Tectonic History of North-central Mexico: Geological Society of America Special Paper, v. 340, p. 191-196, doi:10.1130/0-8137-2340-X.191.

Weber, B., Schaaf, P., Valencia, V. A., Iriondo, A., and Ortega-Gutiérrez, F., 2006, Provenance ages of late Paleozoic sandstones (Santa Rosa Formation) from the Maya block, SE Mexico. Implications on the tectonic evolution of western Pangea: Revista Mexicana de Ciencias Geológicas, v. 23, n. 3, p. 262-276.

Williams, I. S., 1998, U-Th-Pb geochronology by ion microprobe, in McKibben, M. A., Shanks III, W. C., and Ridley, W. I., editors, Applications of microanalytical techniques to understanding mineralizing processes: Reviews in Economic Geology, v. 7, p. 1-35.

Wilson, M., 1989, Igneous Petrogenesis-A Global Tectonic Approach: London, Boston, Sydney, Wellington, Unwin Hyman, p. 466.

Woodhead, J., Hergt, J., Shelley, M., Eggins, S., and Kemp, R., 2004, Zircon Hf-isotope analysis with an excimer laser, depth profiling, ablation of complex geometries, and concomitant age estimation: Chemical Geology, v. 209, p. 121-135, doi:10.1016/j.chemgeo.2004.04.026.

Zindler, A., and Hart, S., 1986, Chemical Geodynamics: Annual Review of Earth and Planetary Sciences, v. 14, p. 493-571, doi:10.1146/annurev.ea.14.050186.002425. 